\title{
心血管デバイス埋め込み手術ナビゲーションにおける表面 曲率に基づいたデバイスの術中三次元位置計測
}

\author{
○片岡 弘之 ${ }^{\mathrm{a}}$, 坂本 徹 ${ }^{\mathrm{b}}$, 高谷 節雄 ${ }^{\mathrm{a}}$ \\ ${ }^{a}$ 東京医科歯科大学生体材料工学研究所, ${ }^{b}$ 同大学院医歯学総合研究科
}

Intraoperative Three-dimensional Localization of Cardiovascular Devices Based on Surface Curvature for Surgical Navigation of Device Implantation

\author{
H.Kataoka ${ }^{\mathrm{a}}$, T.Sakamoto ${ }^{\mathrm{b}}$, S.Takatani ${ }^{\mathrm{a}}$ \\ ${ }^{\mathrm{a}}$ Institute of Biomaterials and Bioengineering, Tokyo Medical and Dental \\ University, Tokyo, Japan \\ ${ }^{\mathrm{b}}$ Graduate School, Tokyo Medical and Dental University, Tokyo, Japan
}

\begin{abstract}
Intraoperative navigation of cardiovascular device implantation is required for the better fit of the devices to the patient's anatomy. In this paper, we presented a methodology of three-dimensional localization of cannula using an optical 3D surface digitizer and the surface curvature estimation in order to achieve non-contact real-time measurement. In the method, the surface of a patient's thoracic cavity was measured using the digitizer, and the cannula surface was isolated from those of the other organs in the cavity according to the cannula specific surface curvature. Finally, the cannula axis was calculated from the isolated cannula surface. We evaluated this method in terms of the isolation performance and calculation speed through in vitro experiments. As the results, it was cleared that surface smoothness should be improved by mean filter, and that the calculation was done within $116 \mathrm{sec}$. We are improving the cannula isolation by using the peripheral and axial vectors of the cannula surface. We will also investigate the possibility of organ isolation with surface curvature mapping in future works.
\end{abstract}

Key words: Surgical navigation, Cardiovascular device, 3D localization, Surface curvature

【背景】重症心不全患者に対する治療では、補助 循環用の心血管デバイスを開胸術によって外科的に 直接心臟に取り付ける(Fig.1)必要が生じる場合があ る。このとき、心臓に対するデバイスの取り付け位 置に依存して、カニューラのくびれによる循環不良 や接続部分の心筇細胞に許容以上の張力を与えると いった問題が発生するため、術中にデバイスの適正

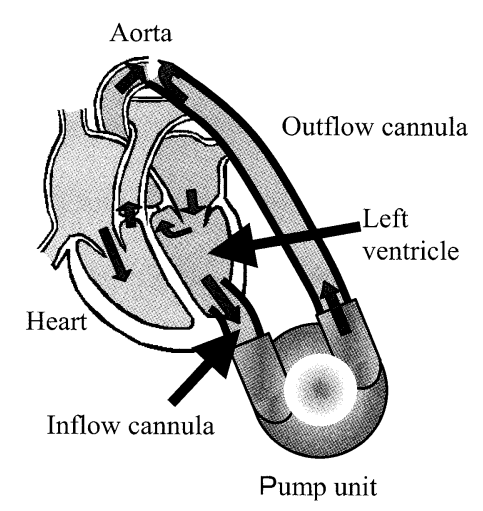

Fig.1 Left Ventricular Assist Device
な位置をナビ ゲーションす るシステムが 有用と考えら れる。そこで 我々は、術中ナ ビゲーション システムの開 発を目標に、心
血管デバイスの三次元位置を術中に計測するシステ ムの開発を行っている。[1]

本研究では、脱血用カニューラの三次元位置を計 測する方法として、埋め込み用デバイスにマーカや センサを直接取り付けるのが困難であることから、 開胸部分から光学式非接触三次元形状測定装置によ って術野の表面形状を測定し、その表面曲率の特徵 からカニューラを区別して術中にリアルタイムに三 次元位置を計測する方法を採用した。また、心臓と 心血管デバイスの模型を用いた in vitro 実験により、 計測精度と速度の評価を行った。

【方法】カニューラの三次元位置計測の概略を Fig.2 に示す。まず、術野の三次元表面形状を光学式 三次元形状測定装置(VIVID910,Konika Minolta Sensing Co.)により計測する。次に、得られた術野各 部の表面形状に対して曲率を算出する。このとき、 


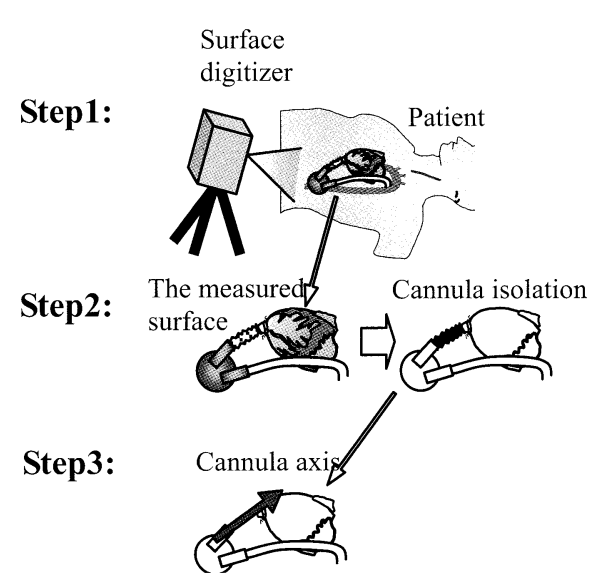

Fig.2 Overview of the cannula localization

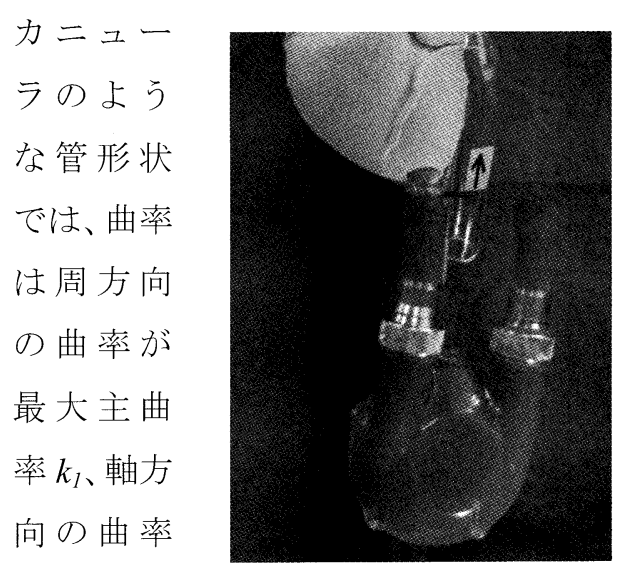

が最小主

曲率 $k_{2}$ と experiments

して $\left(k_{l}, k_{2}\right)$ の組として表現され、また軸と周の方向 も算出される[3]。従って、カニューラの軸のたわみ が大きくなければ、カニューラの管径 $r$ に対して $\left(k_{1} \cong 1 / r, k_{2} \cong 0\right)$ の曲率の領域を抽出することで、カニュ 一ラを管径で特定して臓器や他のデバイスと区別す ることが可能である。これにより、脱血用カニュー ラの表面形状のみを抽出し、周や軸方向を用いてカ ニューラの中心軸の三次元位置と方向を算出する。

この方法におけるカニューラの抽出精度と速度 を、模型(Fig.3)を用いて評価した。特に、曲率の算 出が計測ノイズに弱いことから、形状データへの表 面平滑化（mean および median フィルタ）の適用の 有無の影響と、カニューラ抽出時の径の設定におけ る許容誤差による抽出率、誤抽出率を調査した。

【結果】心臟表面が予想外に平坦で $k_{2}$ によるカニ ユーラとの区別が困難だったため、 $k_{I}$ の值のみで領 域抽出を行った。また、meanフィルタ適用以外は表 面形状のノイズの影響で、カニューラの抽出が困難 であった。Fig.4に mean フィルタ適用の結果を示す。 また、領域抽出時に入力する径とその許容誤差に対 するカニューラの抽出率（手動抽出領域に対する抽 出量) および誤抽出率（手動抽出領域外に対する抽 出量）を求めたところ、径に対しては実際の径 $(10 \mathrm{~mm})$ の入力で抽出率が最大となり、許容誤差の増

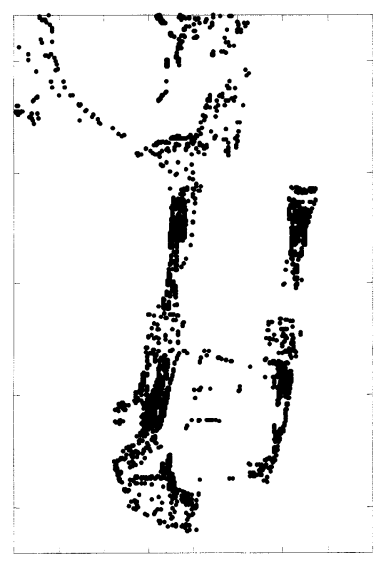

Fig.3 A mockup for in vitro Fig.4 A result of the cannula

加で抽出率と誤抽出率がともに上昇した。計算時間 は、PC(Pentium Xeon 2.5GHz)を用いて 640x480 の形

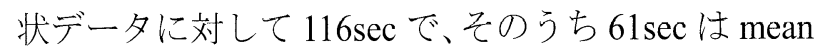
フィルタによる平滑化に要した時間であった。

【考察】領域抽出における径の設定では、実際の 径と低い許容誤差の入力により抽出量を上げ、誤抽 出を低減する必要があるが、算出された周や軸の方 向も考慮に入れることで、より抽出精度を上げるこ とが可能である。また、本手法は冠動脈など表面の 管状臟器の抽出も可能であるので、表面形状に対し て曲率マッピングを作成することで、臟器の認識や 変形の定量化することも今後の課題としたい。

【結論】脱血用カニューラの術中三次元位置計測 の方法として、術野の表面形状の計測と曲率による カニューラの認識を行うシステムを開発した。in vitro 実験により、領域抽出に mean フィルタの適用 を必要とし、また計算時間に $116 \mathrm{sec}$ を費やすことが 明らかとなった。

\section{【References】}

1. 片岡他, 人工心臓埋め込み手術支援システムのた めの人工心臓マーカの開発,第 11 回日本コンピュー 夕外科学会大会論文集,pp.55-56,2002

2. Gray A. Modern Differential Geometry of Curves and Surfaces with Mathematica, 2nd ed. CRC Press 1997. 


\title{
5-Aminolevulinic Acid 誘導による蛍光画像を用いた術中脳腫瘍同定
}

\author{
○清水 一秀 ${ }^{a}$, 小林 英津子 ${ }^{a}$, 丸山 隆志 ${ }^{b}$, 村垣 善浩 ${ }^{c}$, 伊関 洋 ${ }^{b, c}$, 佐久間 一郎 ${ }^{a}$ \\ ${ }^{a}$ 東京大学大学院新領域創成科学研究科, ${ }^{b}$ 東京女子医科大学脳神経外科, ${ }^{\mathrm{c}}$ 東京女子医科 \\ 大学大学院先端生命医科学研究所先端工学外科分野
}
Intraoperative Detection of Brain Tumor by Image Acquisition and Processing based on 5-Aminolevulinic Acid-Induced Fluorescence
K. Shimizu ${ }^{\mathrm{a}}$, E. Kobayashi', T. Maruyama ${ }^{\mathrm{b}}$, Y. Muragaki ${ }^{\mathrm{c}}$, H. Iseki ${ }^{\mathrm{b}, \mathrm{c}}$, I. Sakuma ${ }^{\mathrm{a}}$
${ }^{a}$ Graduate School of Frontier Science, The University of Tokyo, Tokyo, Japan
${ }^{\mathrm{b}}$ Department of Neurosurgery, Neurological Institute, Tokyo Women's Medical University, Tokyo, Japan
${ }^{\mathrm{C}}$ Faculty of Advanced Techno-Surgery (FATS), Institute of Advanced Biomedical Engineering and Science, Graduate School of Medicine, Tokyo Women's Medical University, Tokyo, Japan

\begin{abstract}
An image acquisition and processing method for assisting intra-operative detection of brain tumor and its boundaries using 5-Aminolevulinic Acid(5-ALA), a tumor-marker with fluorescence, is presented in this paper. When 5-ALA was administered to a living body it turns into a fluorescent substance called ProtoporphyrinIX(PpIX) only in pathologic lesion.. PpIX is excited by receiving blue light and emits red fluorescence by which we can know the existence of tumors. The fluorescence image was acquired by a high sensitive CCD camera equipped with an optical filter to eliminate reflected blue light. The image was automatically binarized with a statistic method and its edge was superimposed onto the original image to show the profile of fluorescent area. To perform an animal experiment for evaluation of the system, excessive amount of 5-ALA was administered to a pig. Although automatic detection of the boundary may contain some errors, display of multiple edge detection results under different threshold levels helps surgeon to identify the boundary.
\end{abstract}

Key words: Aminolevulinic acid, 5-ALA, ProtoporphyrinIX, Photo dynamic diagnosis, Brain tumor, CCD camera, Automatic binarization,

\section{1. 緒言}

悪性脳腫瘍の摘出手術においては, 腫瘍の浸潤 性により周辺組織との境界部分が不明瞭である点が 問題となる。その判断は術者の経験・能力に委ねられ るが, 一方で神経組織は再生されないので過度の切 除は脳機能を損なってしまう. 腫瘍の除去率と患者の 予後には密接な関係があるので，脳腫瘍の除去手術 においては必要十分な領域のみの選択的な治療が 理想である。そこで, 腫瘍選択性をもつ物質として，血 液の生合成過程での副産物である 5-Aminolevulinic Acid（5-ALA）を用いた術中腫瘍同定を行う. 5-ALA は術前に患者に投与されると腫瘍細胞のみにおいて 蛍光物質に変化するため, 励起光を照射することで 発生する蛍光により術中に治療対象部位を確認する ことができる1)。これにより，腫瘍の取り残しを防ぎ，同 時に過度の侵襲を避ける事を目的とする。本研究で は術中に腫瘍の検索を行う部位において蛍光を発生 させてその画像を取得し画像処理によって蛍光発生 部位を術者に提示するシステムを構築した。

\section{2. システム構成}

2.0 前提

5-ALA 誘導蛍光物質 (ProtoporphyrinIX: PpIX)の 生体内における吸収波長ピークは $405[\mathrm{~nm}]$, 発光波 長ピークは $635[\mathrm{~nm}]$ である ${ }^{1)}$.

\section{1 蛍光計測装置}

励起光 (半導体レーザ: 406[nm], $18[\mathrm{~mW}]$, Digital Stream co., Tokyo, Japan) を直接照射することで蛍光 を発生させる. 反射光を除去しつつ蛍光のみを輝度と して捉えるため $635 \pm 5[\mathrm{~nm}]$ (FWHM) のバンドパスフィ ルタを備えた CCD カメラ(JK-TU53H/IK-TU51CU, Toshiba co., Tokyo, Japan) で画像を取得する。蛍光 は微弱であるためカメラによりフレーム蓄光を行う。 マ クロレンズとして Micro Nikkor 105mm F2.8 (Nikon co., Tokyo, Japan)を用いる。画像は画像処理ボード IP7000(Hitachi co., Tokyo, Japan) を通じて 512*480 [pixel]の YUV形式でPCに取り込むの. システムの概要 をFig.1 に示す.

2.2 蛍光画像解析ソフトウェア

画像の二值化とエッジ抽出を行い, 元画像に重ね 合わせて表示するソフトウェアを開発した。二值化の 
閾值は, Y 画像のヒストグラムに対して自動閾值選定 を行うことで得た ${ }^{2)}$. 即ち, ヒストグラムを輝度值で二つ のクラスに分けた際に両クラスのクラス間分散とクラス 内分散の比が最大となるような閾值を求める。暗視下 で励起光を照射しフィルタを通して得た蛍光画像から 輪郭を抽出し, 明視下での画像に重祇合わせる事で 蛍光領域を提示する。

\section{3. 実験}

臨床での使用を想定し, 動物実験を行った.ランド レース種のブタに $20[\mathrm{mg} / \mathrm{kg}]$ の 5-ALA を投与し 5 時間 後に開頭して画像の取得を行った。ブタ脳は病的で はなく正常であるが，過剰量の投与により脳表全域に 蛍光を呈するので生理条件下での実験が可能である. 画像中で蛍光領域を限定するため観察用の $10[\mathrm{~mm}]$ 角の穴を開けた板を脳表に設置し，その上から励起 光であるレーザを円形に集光させて約 $59\left[\mu \mathrm{W} / \mathrm{mm}^{2}\right]$ と して照射した. カメラは脳表垂直な向きにに設置して おり視野幅は約 $20[\mathrm{~mm}]$ とした. 明視下での画像を取 得後カメラにフィルタを装着し消灯してレーザを照射し ながら蛍光画像を再取得した。蛍光画像は 30 フレー 厶蓄光（露光時間 $1[\mathrm{~s}]$ ) で撮影した。蛍光画像を Fig.2(a)に，エッジ抽出画像と明視下画像を重ね合わ せた結果をFig.2(b) に示す. また, 蛍光の特性を確 認するために, 分光光度計 (BTC111E, B\&W Tek Inc. DE，USA）を用いて励起光を照射した際の脳表面の 蛍光スペクトルを取得した (Fig.3).

\section{4. 考察}

計測用の孔の中において，おずか $1[\mathrm{~s}]$ の蓄光により 計測に十分な強度の蛍光画像を得ることが出来た. また, Fig.2(b)より, 蛍光強度の強い部分が描出され ており，明視下画像で位置を確認できることが分かる。 画像右側上部において蛍光が弱く輪郭も侵食されて いるのは計測孔によって局面上の脳表に影が出来て しまったためである。Fig.3 のスペクトルは明確な 5-ALA 誘導蛍光の波形を示している. 530[nm] 付近 に自家蛍光と見られる小さいピークが確認できるが, バンドパスフィルタの使用により蛍光のみを適切に選 択できていると考えられる。しかし，正確な輪郭の決定 は基準が曖昧である為に難しい。むしろ, 閾值を連続 的に変化させて蛍光の強度分布を表示するなど, 柔 軟性を持った輪郭選定アルゴリズムを検討する必要 がある。尚，本方法はすでに臨床使用が始まっている 内分泌外科領域での 5-ALA の応用 ${ }^{3}$ においても有
用であると考えられ，導入を検討している。

\section{文献}

1) Walter Stummer, Intraoperative Detection of Malignant Gliomas by 5-Aminolevulinic Acid-induced Porphyrin Fluorescence , Neurosurgery, 42, (3), 518-526, 1998

2) 大津展之, 判別および最小 2 乗基準に基づく自動し きい值選定法, 電子通信学会論文誌, Vol.J-63D, 349-356, 1980

3) 清水一雄, 5-Aminolevulinic $\operatorname{acid}(5-$ ALA) $の$ 応用一 内分泌頸部外科手術に有用かつ簡便な術中副甲状 腺の新同定法一，内分泌外科，21，(3)，2004

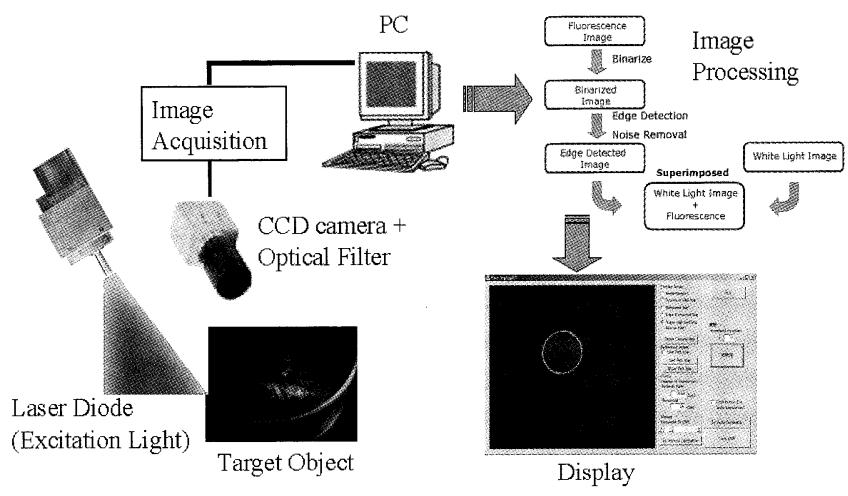

Fig.1 Sytem overview: consisting of a laser diode as excitation light, a CCD camera with an optical filter and a PC for image processing and display
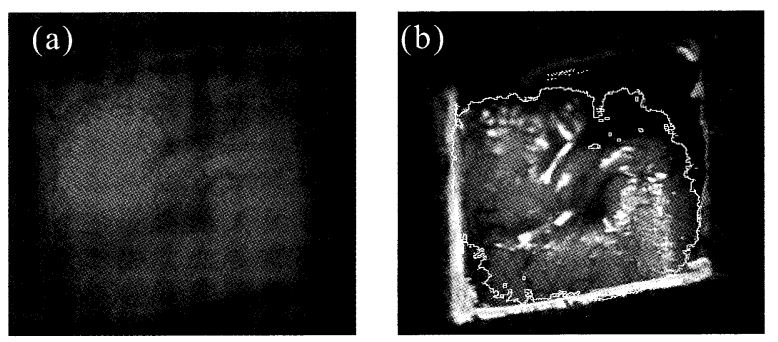

Fig.2 (a) Fluorescence image observed through an optical filter. (b) The original image under white light superimposed with the extracted edge (white line).

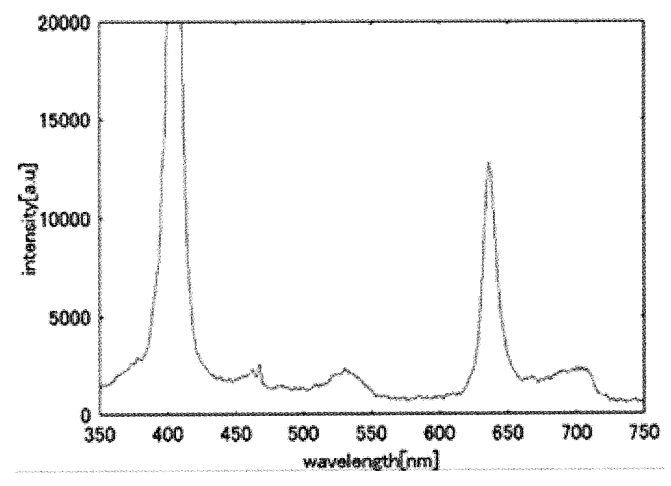

Fig.3 Spectrum from the surface of the fluorescent brain 
副鼻腔囊胞再手術例に対する Tracking System Navigation

\author{
○村田英之 大岡久司 友田幸一 \\ 金沢医科大学耳鼻咽喉・頭頸科 \\ Navigation with tracking system for paranasal cyst revision surgery \\ H. Murata, H. Ohoka, K. Tomoda

\section{Department of Otolaryngology, Kanazawa Medical University, Kanazawa, Japan}

Abstract: Postoperative maxillary cysts are usually monolocular, however, ignoring of polyloculi of maxillary cyst could also result in postoperative residue. Thus it is essential to understand the spatial relationship between loculi preoperatively by means of CT or the other radiological methods. We presented our experience of using navigation system in the operation of a residue case, which was diagnosed as monolocular with CT preoperatively due to the thinness of membrane separating the loculi. Under the guidance of navigation system with tracking system, the residual maxillary cyst was completely removed. Postoperative residue occurs in $20-40 \%$ of polycystic maxillary cyst cases. To avoid this sequela, preoperative radiological evaluation of location of cysts and intraoperative image guiding system are useful.

Key words: Image-guided surgery, Paranasal cyst revision surgery, Tracking system

\section{1.はじめに}

術後性上顎囊胞のほとんどは単胞性だが、 時に多胞性のことがあり手術の際取り残しが 問題点の一つである。多胞性囊胞の手術の際 には術前にCT 等の画像で、囊胞閒の位置関係 を立体的に把握する必要がある。今回は囊胞 間が薄い膜性隔壁で、術前 CT ではあたかも単 胞性に見え、開放時に残存してしまった症例 の再手術に対するナビゲーション機器の有用 性を検討したので報告する。

\section{2. 症例}

63 歳女性で、左煩部痛を主訴に来院。

既往歴として 45 年程前に慢性副鼻腔炎に対

\section{して副鼻腔根本術施行されていた。}

現病歴は初診の約一週間前から続く左煩部 痛を自覚し、当科受診。検査予約し帰宅した が、その夜からやや痛みが増強し、左眼違和 感を自覚。視力障害は認めなかった。眼の違 和感を自覚したためCT (Fig 1) を撮影した ところ、左の上顎骨内にだるま型の囊胞をみ とめ、通常、多胞性囊胞で認められやすい囊 胞間の骨隔壁が認められなかったため、単

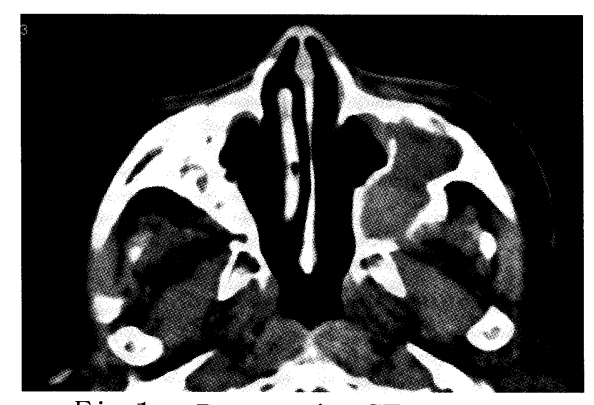

Fig 1 Preoperative CT

胞性と診断。平成 15 年 9 月 29 日鼻内内視 鏡下に襄胞開放術を施行、下鼻道後端やや外 側部より上顎洞囊胞を開放した。同年 10 月 7 日軽快退院。ところが、退院後一ケ月して 再び左眼下方にややしびれ感が出現した。CT (Fig 2 ）を再び撮影したところ、前回開放し

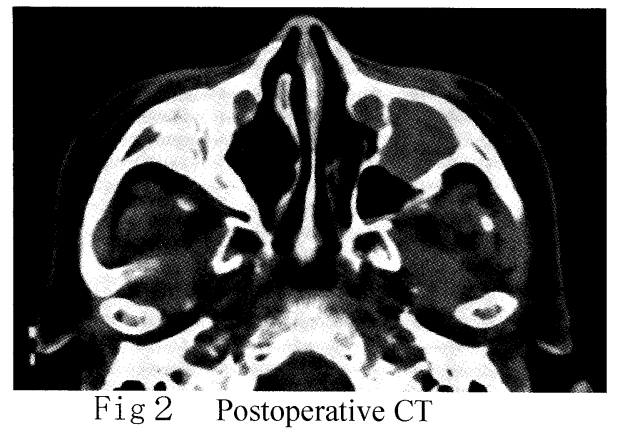

た襄胞部分の前方に残存する襄胞を確認した。 これは囊胞間の隔壁が通常の骨性ではなく、 
膜性であったため、二胞性囊胞があたかも単 胞性と診断してしまった結果と思われる。改 めて手術を予定したが、今度は震胞の残存が ないようにナビゲーションシステムによって 囊胞位置を同定して手術施行することとした。 ここでナビゲーションシステムについて、簡 単に説明する。元来、脳神経外科定位脳手術 用に開発されたもので、そのうちのいくつか の機種が鼻科領域の手術用に改良され、患者 の副鼻腔解剖が術前にCT や MRI をとおしてシ ステムに入力されており、手術モニター画面 が表示され、画像上にプローブの先端の位置 がリアルタイムで表示される。

副鼻腔手術は解剖上、眼、神経、脳が隣り 合わせであるため、術中に同時にみることが できるということが副損傷を防ぐという安全 の面で好まれ、さらに囊胞の位置が危険域に 近い症例、高度病変、再手術症例であれば尚 さらである。今回は、CANS NAVIGATION SYSTEM III （島津製作所）を使用。術前に撮 影したCT がシステム入力されており、実際の 部位と相関させるために座標を登録する。ま た吸引嘴管の先がプローべとなっているため 吸引嘴管の長さや角度を登録する。本システ ムの特徵としてプローベが通過した座標点は 画面上赤く表示され、その部分が最終的に黒 色に変わるため病変が女たかも除去されてい く様子がリアルタイムに表示されるようにな っている（Fig 3 ）。画面術中、画面に存在す る残存囊胞の位置を確認しながら手術をすす め、慎重に確認の上、手術を終了した。

\section{3. 考察}

術後性上顎囊胞について、初回の上顎洞根 本術後に鼻腔と上顎洞の開口部が 15 年から
20 年を経て閉鎖し、上顎洞内に䡒胞が発生 したものをいう。副鼻腔囊胞のなかでもっと

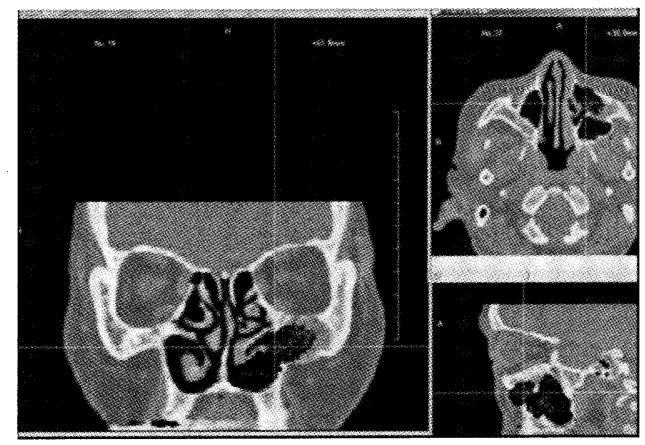

Fig 3 Surgical track navigation system (CANS III)

も症例が多く、多くは経過が緩慢でかつ潜伏 的だが、感染により急に増大し症状を呈する ことがある。症状としては㚘部腫脹、歯痛、 眼痛、鼻涙管圧迫による流涙、ときに複視、 眼球突出、失明などがある。襄胞の数につい て、単房性や多房性のものがあり、そのうち 多胞性のものは施設によってまちまちである が、20〜40\%あるといわれており、今回 のように、取り残しが問題となることがある。

そこで、取り残しを防ぐためには、C Tに よる震胞位置の検討すること、MR I による 囊胞内容の検討すること、3 Dによる立体的 位置把握すること、そして今回使用したナビ グーションシステムによる手術などが重要で あると考える。

参考文献

1、広田 佳治、他: 多房性術後性上顎襄胞 の臨床的研究. 日本耳鼻咽喉科学会、1985 2、村田英之、友田幸一、他 : ナビゲーショ ンを利用した術後性上顎襄胞開放術。日鼻誌 $38: 203-205.1999$

3、鴻信義、春名眞一、森山寬 : ESS におけ るナビゲーションシステムの利用。 JOHNS $16: 52-56,2000$. 


\title{
04(XII)-89
}

\section{脊椎イントゥルメンテーション手術のための 3 次元アライメント計測システム

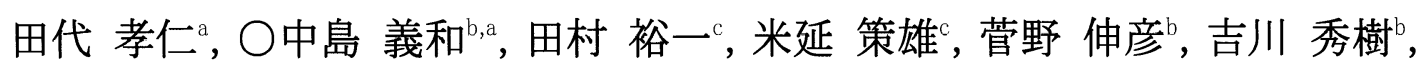 越智 隆弘 ${ }^{\mathrm{d}}$, 田村 進一 ${ }^{\mathrm{b}, \mathrm{a}}$ \\ 大阪大学 $\left\{a\right.$ 大学院情報科学研究科, ${ }^{b}$ 大学院医学系研究科 $\},{ }^{c}$ 大阪南医療センター, ${ }^{d}$ 相模原病院}

\section{3-D Alignment Measurement System of Segments for Spinal Instrumentation Surgery}

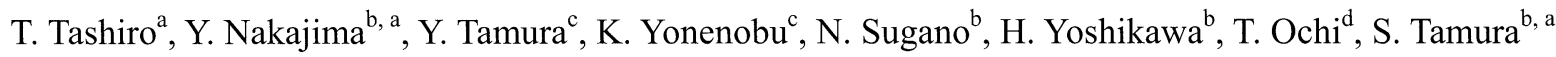

${ }^{a}$ Graduate School of Information Science and Technology, Osaka University, Osaka, Japan

${ }^{\mathrm{b}}$ Graduate School of Medicine, Osaka University, Osaka, Japan

c Osaka Minami Medical Center, Osaka, Japan

${ }^{\mathrm{d}}$ Sagamihara National Hospital, Kanagawa, Japan

\begin{abstract}
We have been developing a 3-D alignment measurement system of segments for spinal instrumentation surgery. This system employs a novel measurement method of pre- and post-operative spinal alignment in standing position and intra-operative alignment of the treated spinal segment by using a CT-based surgical navigation system. The accuracy of the pre- and post-operative measurement system was $0.27 \mathrm{~mm}$ for translation and 0.11 degree for rotation. The accuracy of the intra-operative measurement system was $0.48 \mathrm{~mm}$ for translation and 0.12 degree for rotation.
\end{abstract}

Key words: Computer assisted surgery, Surgery evaluation, Spinal alignment measurement

\section{1. はじめに}

3 次元手術計画システムおよび手術ナビゲーションシ ステムの導入は, より安全で多角的情報に基づく手術の 実現に加え, 手術の定量記録を可能にする. 手術の計 画, 状況, および結果を定量記録し,データとして蓄積し ていくことは, 手術の定量解析, 特に, 成績の良／悪グ ループ間における差異の定量解析が可能になる点で有 用である.

我々は, 術前診断, 手術計画, 術中ガイド, 術後評価 を含む統合的な手術記録／評価システムの構築を目指 し, 脊椎イントゥルメンテーション手術を対象としたシス テムの開発を行ってきた[1]. 脊椎アライメントの矯正, 保 持はこの手術の要点であり, 術前のレントゲン写真などに 基づいて適正なアライメントを計画する. 従来では, 術前 /術後の脊椎アライメントの比較は 2 次元 X 線画像のみ で行われており, 3 次元で解析されていなかった。 また, 従来の手術ナビゲーションシステムでは, 術中に脊椎アラ イメントを計測／ガイドする機能は有しておらず，矯正は 術者の経験と勘に頼る部分が大きく, 術中において術前 計画を必ずしも客観的に反映させていなかった.

今回, 我々が構築したプロトタイプシステムにおいて, 術前/術後, および術中の脊椎アライメントの計測精度 を検証したので報告する.

\section{2. 方法}

\section{1 術前/術後アライメント計測}

術前／術後の脊椎アライメント計測を目的として, 背卧 位で術前に撮影された CT 画像と，立位で術前あるいは 術後に撮影された単純 X 線画像から, 立位の $\mathrm{CT}$ 画像を 再構成する手法[2]について述べる. 本手法は, 位置関 係が未知の 2 視点 $\mathrm{X}$ 線撮影画像からの物体の 3 次元ア
ライメント計測法である. ステレオ X 線撮影装置など新た な装置を必要とせず, 現在の診療プロトコルを大きく変更 することなく利用可能である. 手順を以下に示す.

A)CT 画像撮影および前処理：術前にアライメント計測 対象となる椎骨を含む領域の CT 撮影を行う. 次に, セグ メンテーション・アプリケーションを用い, CT 画像から各椎 骨領域の画像を抽出した画像 (以下, セグメント画像と表 す)を作成する.さらに, アライメント矯正計画アプリケーシ ヨンおよび手術ナビゲーションシステムの入力データとし て, 各椎骨の表面形状モデルを作成する.また, アライメ ントを数值化するため, 各椎骨の CT 画像上で脊椎骨の 特徵点を指定し, ローカル座標系を設定する(Fig. 1).

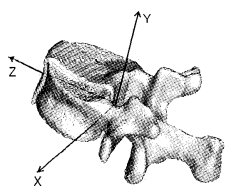

Fig. 1 Local coordinate system of a vertebra

B)立位 X 線撮影：まず, X線撮影系の内部パラメータ (焦点距離, 画像中心座標)を求めるため, 既知形状の キャリブレーションフレームを撮影する. 次に, 患者の X 線撮影を行う. 患者のX 線撮影では, 一般臨床における 撮影と同様，正面および側面の 2 視点からの撮影を患者 の向きを変えて行う (Fig. 2(a),(b)).ここでは, 3 次元で脊 椎アライメントを推定するために, 2 回の X 線撮影間にお ける患者の春椎アライメントをできる限り一致させて (姿勢 を変えないようにして) 撮影することを条件とする.

C)アライメント推定：アライメント推定では, 撮影系に対 する患者の移動 (Fig. 2(a),(b))を, 患者に対する撮影系 の移動 (Fig. 2(c)) に置き換えることで, 仮想的に 2 視点 からの撮影を実現する. 最適化は, POCS 法の枠組みで 
行う. 推定アルゴリズムを以下に示す. (1)Fig. 2(c)のよう に, 2 回の撮影を 2 視点からの撮影に置き換え, CT 画像 に対する撮影系の初期位置をインタラクティブに設定す る. (2)2つの撮影系の位置姿勢を固定して各椎骨のセグ メント画像をレジストレーションし, それらの位置姿勢を更

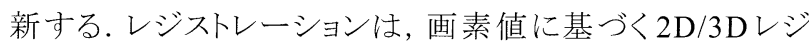
ストレーション法[3]を用いて行う. (3)各椎骨セグメント画 像間の相対位置姿勢を固定し，それに対して 2 つ撮影 系をそれぞれ独立にレジストレーションすることで，2 つの 撮影系の位置姿勢を更新する. (4)手順 2 および 3 を, 各 推定值の更新幅が十分に小さくなるまで繰り返す.
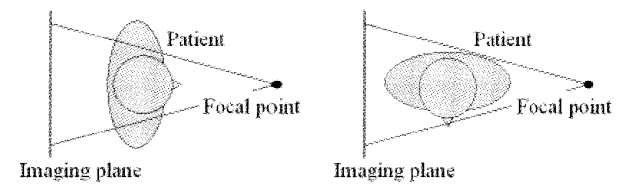

(a)

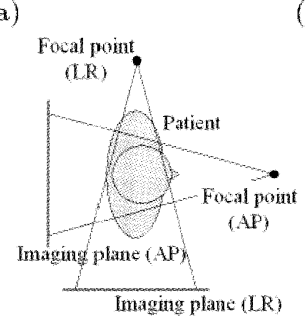

(c)

Fig. 2 X-ray imaging; (a)frontal view, (b)lateral view. (c)Geometries in the estimation algorithm.

\section{2 アライメント矯正計画}

アライメント矯正計画は, 術前に, 各椎骨の表面形状 モデルを使って行う. 各椎骨の表面形状モデルは, 2.1 節の手順 A で作成したものを使用する.まず, 術前の立 位アライメント, すなわち 2.1 節の手順 $\mathrm{C}$ で求めた各椎骨 セグメント画像の位置姿勢マトリクスに従って, 各椎骨の 表面形状モデルを配置する. 矯正計画は, 医師が, 各椎 骨に関して, 手順 A で設定したローカル座標系での椎骨 の矯正量 (回転／平行移動量)をアプリケーションの GUI でインタラクティブに操作し，アライメントを確認しながら表 面形状モデルの位置姿勢を変更することで行う.

2.3 術中アライメント計測

術中の脊椎アライメントは手術ナビゲーションシステム で計測する.まず, 計測対象となる椎骨に3 次元位置計 測マーカを固定, 表面レジストレーションによりマーカに対 する椎骨の相対位置姿勢を決定する. 次に, マーカの位 置姿勢を逐次計測して, アライメント計測を行い, さらに, 術前計画との差分を呈示して, 矯正のナビゲーションを 行う.

\section{3. 実験}

3. 1 術前 / 術後アライメント計測精度 術前 / 術後アライメント計測の精度を Fig. 3 に示す.
提案手法の精度は $0.27 \mathrm{~mm}, 0.11$ degree であり, 2 視点 撮影画像からの推定結果と同等であった. 1 視点撮影画 像からの推定結果において, 誤差の大半は撮影系の奥 行き方向の軸に沿った成分であった. それと比較して, 2 方向撮影画像からの方法および提案手法ではこの成分 の精度が大幅に向上していた。

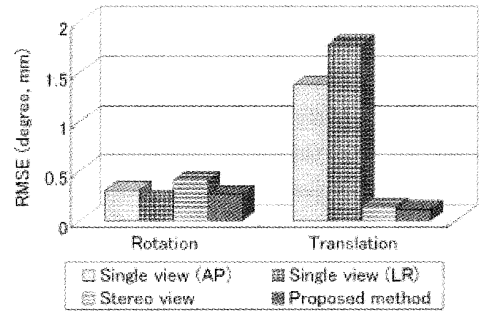

Fig. 3 Estimation accuracy of pre-/post-operative alignments. Single view, stereo view, and proposed method represent the estimation method from single-view imaging, the estimation method from stereo-view imaging, and proposed method, respectively. AP and LR represent frontal view and lateral view, respectively.

3.2 術中アライメント計測精度

モデル骨を用いて手術と同手順による操作を行い，実 験を行った. 実験は, トラッカの付替えを含む 20 回の操 作に対して, 各 50 回の計測を行った. 計測の RMS 誤差 は $0.48 \mathrm{~mm}, 0.12$ degree であった。

\section{4. まとめ}

脊椎インストゥルメンテーション手術において, 春椎ア ライメントを術前／術中／術後にわたって統合的に 3 次 元計測するシステムを構築し, 推定精度を検証した。術 前 /術後の脊椎アライメント計測精度は, 2 視点撮影画 像からのアライメント推定精度と同等の良好な結果を得た。 術中計測も臨床に応用可能な推定精度であった。

現在のシステムは, 術前／術後解析のためのコマンド 群を中心とするアプリケーションと, 術中ナビゲーションシ ステムで構成されている. 今後, 統一したインタフェースに よる各機能の一体化を行い, 臨床ルーチンでの稼動を目 指したい.

\section{文献}

1) 中島義和, 田村裕一, 田代孝仁ら, 脊椎アライメン トの 3 次元定量化による手術支援システム，第 12 回日本コンピュータ外科学会大会抄録集, pp.105-106, 2002.

2) 田代孝仁, 中島義和, 田村裕一ら, 2-D/3-D レジス トレーションを用いた春椎の立位 3 次元アライメント 計測，信学技報 MI2003-32, 103(213), pp.31-36, 2003.

3) J. Weese, G.P. Penney, P. Desmedt, et.al, Voxel-based 2-D/3-D registration of fluoroscopy images and CT scans for image-guided surgery, IEEE Trans. Information Technology in Biomedicine, 1(4), pp.284-293, 1997. 


\title{
04(XII)-90 簡易ユーザインタフェースを備えた超音波画像誘導 RFA 穿刺ナビゲーションシステムの開発
}

\author{
○縣麻華里, 正宗賢, 折田純久 ${ }^{1)}$, 中郡聡夫 ${ }^{2)}$ \\ 宮内英聡 ${ }^{1)}$, 貝沼修 ${ }^{3)}$, 浅野武秀 ${ }^{3)}$ \\ 東京電機大学理工学研究科, 千葉大学大学院医学研究院 ${ }^{1)}$ \\ 国立がんセンター東病院 ${ }^{2)}$, 千葉県がんセンタ一消化器外科 ${ }^{3)}$
}

\section{Ultrasound Image Guided Navigation system}

for RFA needle insertion therapy equipped with the simple user interface
A. Agata, K. Masamune, S. Orita ${ }^{1)}$, T. Nakagori ${ }^{2)}$,
H. Miyauchi ${ }^{1)}$, O. Kainuma ${ }^{3)}$, T. Asano ${ }^{3)}$
Graduate School of Science and Engineering Tokyo Denki University,
Graduate School of Medicine Chiba University "),
National Cancer Center Hospital East ${ }^{2)}$, Chiba Cancer Center ${ }^{3)}$

\begin{abstract}
Radiofrequency Ablation (RFA) is a low invasive treatment to eliminate liver cell cancer. RFA needle is used to irradiate Radiofrequency wave. Tumor is cauterized by applying Radiofrequency wave, and RFA can make tumor necrose. General RFA needle is placed in tumor, position and the size of tumor is measured from ultrasound image. It is necessary to make two or more times insertion tumor depending on the size of a tumo r. However it is hard to control the position of needle because the whole view of tumor can not be obtained clearly by micro bubble generating in the first cauterizing. In this study we developed the simple navigation system which can be used in an inspecting room. And also it can display and measure relative information of position on an ultrasound image, RFA, and an insertion position.
\end{abstract}

Key words: Radiofrequency Ablation (RFA), Navigation, Ultrasound Image Guided, Liver cancer

\section{1. 研究背景および目的}

肝細胞癌や転移性肝癌に対する低侵襲な治療法とし て注目されている一つにRFAがある.これはRFA 電極二 一ドルを腫瘍に穿刺し, その先端からラジオ波を照射して 腫瘍を焼灼し, 壊死させる手法である. 現在 RFA 二ード 儿を穿刺する際, 超音波画像より腫湟位置の把握を行い, 腫瘍の大きさによっては複数回の穿刺を行う必要がある が，一度目の焼灼時のマイクロバブル発生により腫瘍の 全体像が得られず, 正確な穿刺が困難となることが多い. 本研究では, 超音波画像, RFA, 穿刺刺入位置の相対位 置情報のみを計測・表示し, 検査室内でも用いることが出 来るシンプルなナビゲーションシステムの構築とキャリブ レーションを行ったので報告する.

\section{2. システム構成}

本システム(Fig.1 参照)は光学式3次元位置計測装置 (Polaris,NDI 社製), 画像処理カード内蔵 PC, PCMCIA ビ デオ・キャプチャーカード(Video Capture Essentials Professionals, ImperX 社製), 超音波診断装置(GE 横河入 ディカル社製, LOGIQ $\alpha$ 200MD)からなる. RFA 用穿刺 針に Polaris 付属の位置・姿勢計測用赤外線 LED マ一力

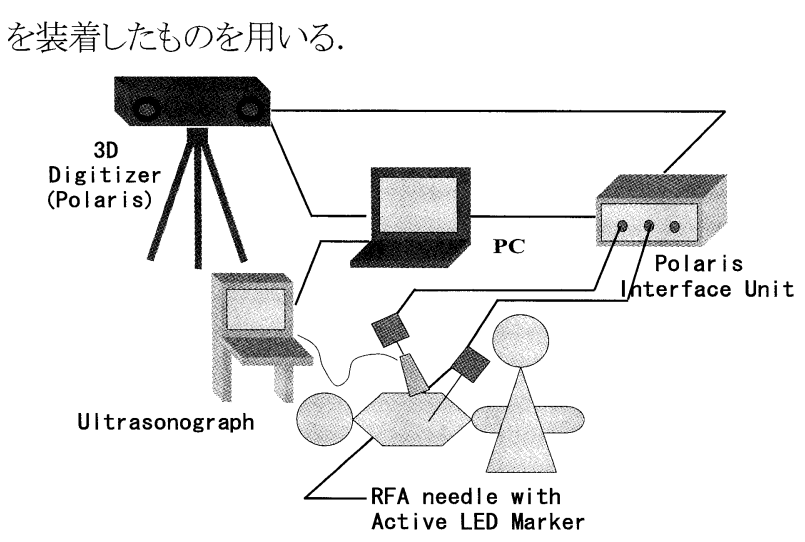

Fig.1 System configuration

\section{3. 簡易ユーザインタフェース}

本システムでは，1.ターゲット(腫瘍)の位置情報を超 音波画像上をクリックすることにより取得, 2. ナビゲーショ ン画面に表示されているターゲットと刺入点が一致する位 置を決める, 3. 刺入点を基点に穿刺針を動かし, 刺入点 とターゲットが一致する角度で深さバーを確認しながら刺 入を行う, といら3ステップで簡単に腫瘍に到達可能であ る. また, 画面右に超音波画像を表示することから, 従来 
通りの情報も同時に得ることができる.

Fig.2 にユーザインタフェース画面を示寸. 超音波画像 の範囲, さらに穿刺針がどの程度刺入されたかを確認す るための深さバーから構成されている. 画面左上がナビ ゲーション画面であり,グラフイックスは OpenGLを用いて 作成した. 画面右上に超音波診断装置から取得した超音 波画像を表示している.

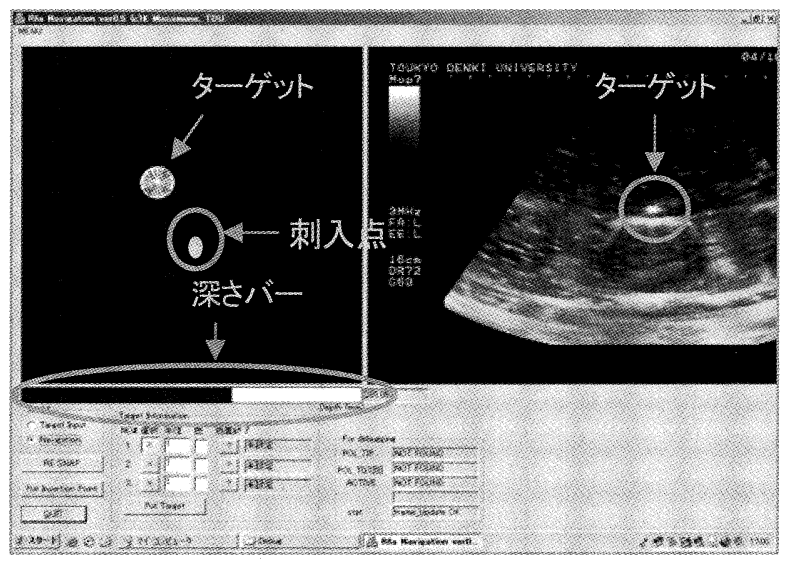

Fig.2 User interface of the system

\section{4. キャリブレーション・座標変換}

本システムにおける関連座標系をまとめたものを Fig.3 に示寸. 穿刺針と穿刺針先端座標, 超音波プローブと超 音波画像座標系は事前にキャリブレーションが必要であ る. また, 患者は呼吸などの体動のみで大きく動かないこ とを前提にしているため, 患者自身の位置のキャリブレー ションは行わない.

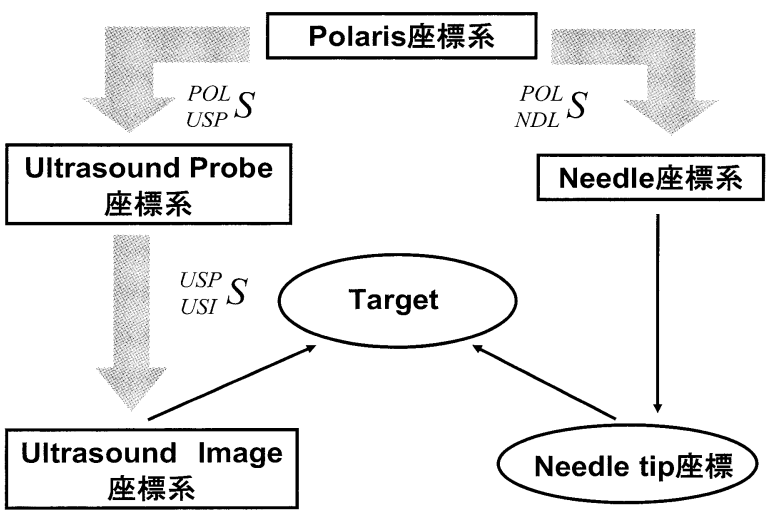

Fig.3 The relation of a coordinate system

[RFA プローブキャリブレーション]穿刺針にアクティブマ 一カを装着し, 穿刺針の根元と先端をパッシブマーカで 指示し, 穿刺針 $\rightarrow$ 穿刺針先端座標間の位置関係を計測 した. 座標変換には式(1)を用いた. 穿刺針座標系から みた穿刺針先端座標を ${ }^{N D L} X_{N D L t i p}$, ポラリス座標系から
みた穿刺針先端座標を ${ }^{P O L} X_{N D L t i p}$ とする.

$$
{ }^{N D L} X_{\text {NDLtip }}={ }_{N D L}^{P O L} S^{-1} \cdot{ }^{P O L} X_{\text {NDLtip }} \quad \cdots \text { 式(1) }
$$

10回計測を行い, 計測結果の座標の標準偏差を算出 し, 作成したプログラムの確度をみた.

[超音波画像キャリブレーション]専用ツールを作成し, 水 槽に浸し超音波画像に写るツールのピン 3 点を元に対応 させ, 超音波プローブに取り付けたアクティブマーカと画 像の座標との関係を測定した. 座標系変換には式(2)を 用いた。

$$
{ }_{U S I}^{U S P} S={ }_{U S P}^{P O L} S^{-1} \cdot{ }_{U S I}^{P O L} S \quad \cdots \text { 式(2) }
$$

\section{5. 考察と結語}

RFA プローブキャリブレーションで計測結果から算出し た標準偏差は X=0.75(mm), Y=0.84(m), Z=0. $35(\mathrm{~mm})$ で あった. RFA 穿刺針部分が力を加えると簡単にたわんでし まうことから，このたわみが原因と考えられる．RFA 穿刺針 は今回鋼体として考え, たわみは考慮に入れずにキャリ ブレーション方法およびプログラムの作成を行ったが, 実 際の治療においては穿刺時に加える力によりたわみが発 生し誤差が大きくなることも考慮に入れ，今後は穿刺針先 端を確実に追跡可能な方法を考える必要がある.

今回, ナビゲーション画面の表示は OpenGL を用いて 作成している.しかし，現在では画面上にターゲットと刺 入点の表示しか行っておうらず, 周辺情報は画面右の超音 波画像を見ながら得ている. したがって,このナビゲーシ ヨン画面に超音波画像をテクスチャマッピングすることに よって，より迅速に，また正確に刺入点を決定することが できると考えられる。

本システムはノート PC で構成されているため, 検査室 などでも治療を行うことが出来るシンプルなシステムであ る.また，現在は術者および患者の姿勢による視線方向 を固定した場合のみを考えインタフェースを構築している が, 今後は術者もしくは患者の姿勢も含めたインタフェー スの改良およびナビゲーション精度向上のための改良を 中心に行う. なお，本研究の一部は COE プログラムの助 成による.

[参考文献]正宗，水谷ほか: “超音波画像誘導 Radiofrequency Ablation(RFA)における穿刺ナビゲーショ ンシステムの開発”, 医用電子と生体工学 vol42.suppl.1,

\section{P668, 2004}

折田, 丸山ほか: “Radiofrequency Ablation(RFA)における 穿刺ナビゲーションシステムの開発”, 日本コンピュータ 外科学会論文集, p61-62, 2002 
04(XII)-91

手術支援ナビゲーションロボットにおける操作性の評価

○門脇 吉則 ${ }^{a}$, 長縄 明大 ${ }^{a}$, 正宗 賢 ${ }^{b}$

$\mathrm{a}$ 秋田大学, b 東京電機大学

\author{
Evaluation of Manipulation for Surgical Support Navigation Robot \\ Yoshinori KADOWAKI ${ }^{\mathrm{a}}$, Akihiro NAGANAWA ${ }^{\mathrm{a}}$, Ken MASAMUNE ${ }^{\mathrm{b}}$ \\ ${ }^{a}$ Faculty of Engineering and Resource Science, Akita University, Akita, Japan \\ ${ }^{\mathrm{b}}$ School of Science and Engineering, Tokyo Denki University, Saitama, Japan
}

Abstract: The surgical navigation robot is used in order to position the instrument correctly to the target disease. The development of a MRI compatible navigation robot is also recently started so as to utilize more rich information of the MRI imaging. However, the evaluation of the relative relationship between a robot's position-posture and the surgeon's hand's position-posture is not well considered especially in a narrow surgical space until now. In this research, we propose one method for evaluating the surgeon hand's operatively to use for the design of the robot. The manipulability ellipsoid and the manipulating force ellipsoid are applied to evaluate hand motions to estimate the validity of the operability of the robot in the surgical field.

Key words: Navigation robot, Operatively evaluation, Manipulability ellipsoid, Manipulating force ellipsoid

\section{1. 緒言}

手術支援のために使用されるナビゲーションロボ ットは, 術者の使用する器具などを, 正確に目的と する患部に位置決めするために使用され，術者の 手ぶれ補償に効果的である. 最近では, MRI 画像 のもつ有益な情報を術中に反映させるため，MRI 対応型のナビゲーションロボットの開発も行われてい $る^{1)}$. しかし, 口ボットの位置姿勢と術者手先の位置 姿勢との相対関係の定量的評価はこれまで行われ ておらず, 術者が必ずしも操作性の良い姿勢で手 術を行えているかどうか検討されていない。

そこで, 本研究では, 術者手先の操作性を評価 する一つの方法を提案する. 本研究の手法は, ロボ ットマニピュレータの機構評価として用いられている 可操作性楕円体および操作力楕円体により手先運 動の評価を行い, 患部に対して使用寸る医療器具 が操作しやすいかじうかを評価するものである ${ }^{2)}$.

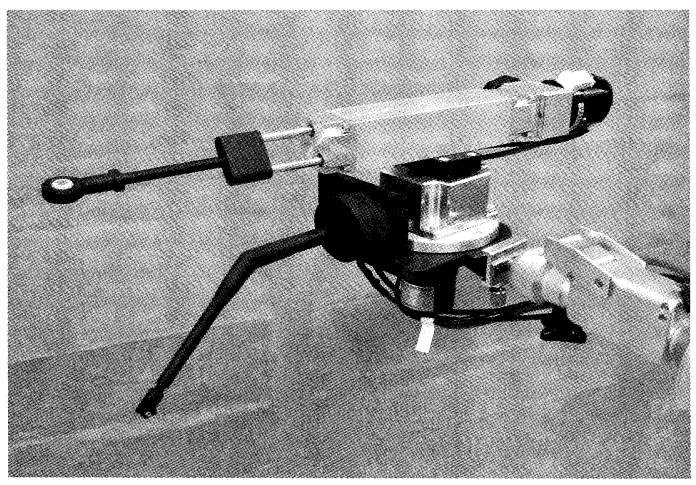

Fig.1 Navigation robot

\section{2. 操作性の評価方法}

本研究では, Fig.1 に示す穿刺治療支援モジュラ 一型ナビゲーションロボットに対して操作性の評価 を行う.このロボットは, Fig.2 に示すように穿刺やドリ ルでの穴あけを行う際の手ぶれの補償を目的として いる.これにより, 患部への確実な位置決めを実現 できるとともに，手ぶれ等による医療事故の軽減を 図ることができる.ロボットの機構は, 直動機構と回 転機構を組み合わせた 2 自由度であるが，患部に 対してロボットの姿勢を任意に変更することができる 14 自由度のパッシブアームに取り付けられる。

このロボットに対する操作性を評価するため, 術 者の上肢をリンクモデルとして表現する．上肢は，一 般に, 肩関節 3 自由度, 时関節 1 自由度, 手関節

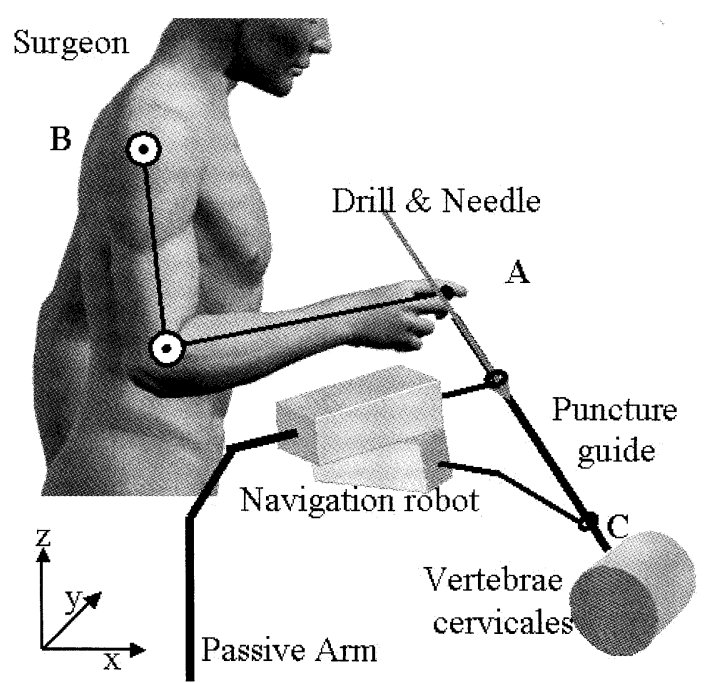

Fig.2 Situation of medical treatment 
3 自由度の計 7 自由度で表現される. しかし, 本研 究では解析を簡単化するため, 右腕を前後に動か してできる平面，すなわち，Fig.2 における XZ 平面 内の運動のみ考える。これにより, 術者は手首を固 定したまま右腕を前後に動かす運動を行い, 肩関 節 1 自由度, 时関節 1 自由度として上肢をモデル 化できる.

ロボットに対する操作性は, ナビゲーションロボット がすでに位置決めされており，このロボットに対して 術者が姿勢を変化させたとき, 手先運動の操作性 を評価する．操作性の評価は，ロボットマニピュレー タの機構評価に用いられている可操作性楕円体お よび操作力楕円体を用いる. 可操作性楕円体は, 関節空閒と手先の作業空間の運動を関係付ける ヤコビ行列の特異值分解により計算することができ, 楕円体の主軸の長さ方向は, 手先速度を出しやす い方向を表現する。この楕円が球に近いほど，あら ゆる方向に手先の動かしやすさ，つまり操作のしや すさを表現する.上肢の姿勢が変わると操作性が変 わるが，このときヤコビ行列も変わるため，作業空間

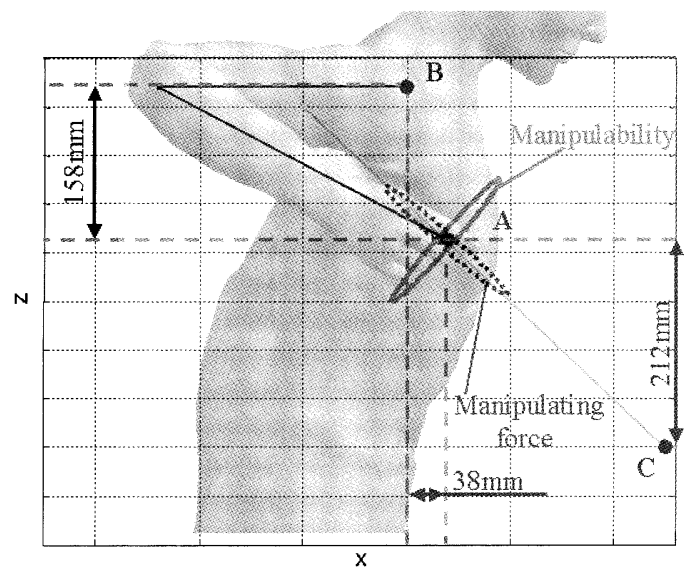

(a) Case 1

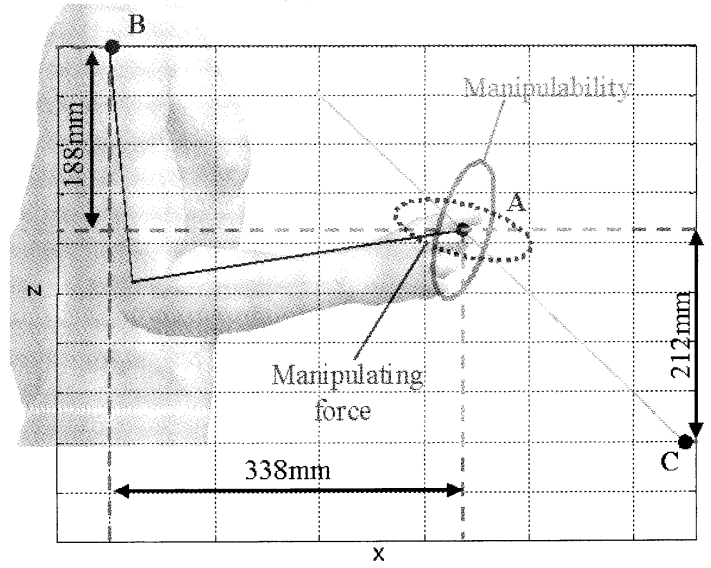

(b) Case 2

Fig.3 Evaluation of operatively
における棈円体の形状変化を求めることにより，操 作性の評価を行うことができる. 一方, 操作力楕円 体は，手先が対象に加えることができる力の方向を 示し, 可操作性楕円体に対して, 主軸を $90^{\circ}$ 回転 させた方向となる.

\section{3. 評価結果}

前章の条件のもとで行った評価結果について述 べる. 本研究では, Fig.2 における手先の位置 A 点 (穿刺ガイド入り口) を固定し, 術者の姿勢が変化 (肩の位置 B 点が変化)した場合の操作性について 検討する。術者の上肢の長さは，肩から肘までが $240 \mathrm{~mm}$, 时から手先までが $320 \mathrm{~mm}$ とした. また, 想 定した患部 $\mathrm{C}$ 点から $\mathrm{A}$ 点の高さは, $212 \mathrm{~mm}$ である.

Fig.3 は, 評価結果を示しており, Fig.3 中には, 術者右腕の姿勢イメージとともに, A 点の周りに可 操作性楕円体 (実線) および操作力楕円体 (点線) が示されている.ここで, Case 1 は患部を上方から確 認しながらの操作を, Case 2 は患部を斜め上方から 確認しながらの操作を想定している. 上肢の長さは 2 つのCase で等しいため, 術者の肩の位置 B 点と A 点との距離が, 両者で異なる. Fig.3 に示されるよ うに, Case 1 では患部方向に対して可操作性楕円 体の短軸方向がほぼ一致しているため, 操作性は 悪いものの, 可操作力では長軸方向と一致するた め大きな操作力を発生できる. 一方, Case 2 では, それぞれの楕円が Case 1 より円に近い形状をして おり，操作性と操作力のバランスが Case 1 より取れ ているといえる.

\section{4. 結言}

本研究では, 手術支援ナビゲーションロボットに 対する術者の操作性の評価として, 可操作性楕円 体および操作力楕円体に基づく方法を提案した. シミュレーションでは, 穿刺における操作性に関する 評価を行い, 術者の姿勢が手先の操作性と操作力 に影響を与えることを定量的に示した。 今後の課題 として, 本発表では 2 次元空間の解析を行ったが, これを 3 次元空間に拡張すること,また, 今回はロボ ツトを固定して解析を行ったが, ロボットの姿勢も変 化させた場合の相対評価についても検討を進める.

\section{参考文献}

1) 長能, 正宗, 伊関, 中島:MRI 対応穿刺治療 支援モジュラー型ナビゲーションロボットの開発 に関する研究, 日本コンピュータ外科学会誌, Vol.5, No.3, 343/344, 2004

2) 吉川:ロボット制御基礎論, コロナ社, 1988 


\title{
04(XII)-92 磁気式位置センサを用いた気管支内視鏡ナビゲーションに関する 予備的検討
}

\author{
○秋山 健太 ${ }^{\mathrm{a}}$, 出口 大輔 ${ }^{\mathrm{a}}$, 北坂 孝幸 ${ }^{\mathrm{a}}$, 森 健策 ${ }^{\mathrm{a}}$, 末永 康仁 ${ }^{\mathrm{a}}$, 鳥脇 純一郎 ${ }^{\mathrm{b}}$, \\ 名取 博, 高畠 博嗣, 森 雅樹 ${ }^{\mathrm{e}}$ \\ a 名古屋大学大学院情報科学研究科, ${ }^{\mathrm{b}}$ 中京大学生命システム工学部 \\ ${ }^{\mathrm{c}}$ 札幌医科大学医学部, ${ }^{\mathrm{d}}$ 札幌南三条病院, ${ }^{\mathrm{e}}$ 札幌厚生病院
}

\section{A Preliminary Study on Bronchoscope Navigation using Magnetic Positional Sensor}

Kenta Akiyama $^{a}$, Daisuke Deguchi ${ }^{a}$, Takayuki Kitasaka ${ }^{a}$, Kensaku Mori ${ }^{a}$, Yasuhito Suenaga ${ }^{a}$, Junichiro Toriwaki ${ }^{\mathrm{b}}$, Hiroshi Natori ${ }^{\mathrm{c}}$, Hirotsugu Takabatake ${ }^{\mathrm{d}}$, Masaki Mori ${ }^{\mathrm{e}}$

${ }^{a}$ Graduate School of Information Science, Nagoya University, Japan

${ }^{\mathrm{b}}$ School of Life system science and Technology, Chukyo University, Japan

' School of Medicine, Sapporo Medical University, Japan

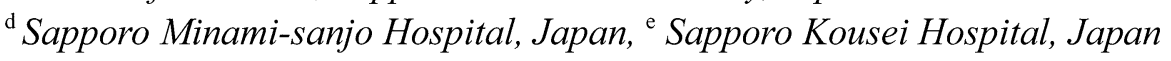

\begin{abstract}
This paper describes a method for bronchoscope navigation based on position data outputted from a magnetic positional sensor. We have developed a bronchoscope navigation system based on image similarity between real and virtual endoscopic images. This method enables us to estimate camera motion with a high degree of accuracy. However, it spends a lot of time for estimating camera positions. The proposed method uses a miniature-sized magnetic positional sensor and calculates a camera position based on transformation of the coordinate system between a 3D X-ray CT image and a positional sensor. We applied the proposed method to a rubber bronchial model. In the experimental results, the proposed method could obtain camera motion in real time on a 3D X-ray CT image. Fiducial Registration Error (FRE) was about $1.53 \mathrm{~mm}$ in the proposed registration method.
\end{abstract}

Key words: navigation, bronchoscope, positional sensor

\section{1.はじめに}

近年，低侵襲な検査・手術として内視鏡検査・内 視鏡下手術が注目されているが，内視鏡から得られ る画像の視野が狭いため内視鏡操作に熟練が必要, 臓器壁面下の血管位置等の重要な情報を直接得るこ とが不可能といった問題がある。そこで，我々はこ れまでに，気管支鏡から得られる情報と仮想化内視 鏡から得られる情報を融合した気管支内視鏡ナビゲ ーションシステムの開発を行ってきた[1]. 本システ ムでは，現在の観察位置，気管支の樹状構造や気管 支枝の解剖学的名称, 臓器壁面下の血管位置などを 術中の医師に提示することが可能である.このシス テムを実現するためには, CT 像における実内視鏡の 現在位置や姿勢を常に取得する必要がある。これま では，空間的制約のために気管支鏡等の軟性鏡の先 端に位置センサを取り付けることは困難であった. そのため, 実内視鏡像と仮想化内視鏡像の画像間類 似度を基に内視鏡の動き推定を行ってきた。現時点 では，1 フレームを処理するのに 2〜3 秒程度要し， 実時間で動きを推定するには至っていない.しかし， 超小型磁気式位置センサの登場により，位置センサ を用いたリアルタイム内視鏡ナビゲーションシステ
ム実現の可能性が出てきた。そこで本稿では，位置 センサを用いた実内視鏡の位置推定の予備的検討と して，磁気センサと CT 像の座標系の位置合わせ実 験を行ったので報告する。

\section{2. 位置合わせ手法}

気管支ファントムの 3 次元 X 線 CT 像，実内視鏡 ビデオ，位置センサから得られる 3 自由度の並進情 報を入力とし, 並進情報を用いて磁気センサと CT 像の座標系の位置合わせを行う。具体的には，3 次 元 $\mathrm{CT}$ 像と位置センサの座標系を次に示す変換式で 対応付ける。

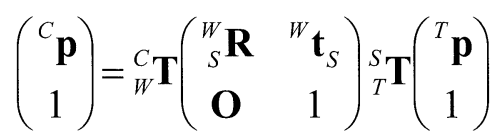

ここで， ${ }^{C} \mathbf{p}$ は CT 座標系における内視鏡の観察位置 を表す位置ベクトル， ${ }^{T} \mathbf{p}$ はセンサ座標系におけるセ ンサの位置を表す位置ベクトルであり，位置センサ の先端から出力される. また, ${ }_{W}^{C} \mathbf{T}$ はワールド座標系 から CT 座標系への変換行列, ${ }_{S}^{W} \mathbf{R}$ はセンサ座標系 からワールド座標系への回転行列, ${ }^{W} \mathbf{t}_{S}$ はセンサ座 標系からワールド座標系への平行移動ベクトル， ${ }_{T}^{S_{T}}$ はセンサ先端で定義される座標系からセンサ座標系 
へのセンサキャリブレーション行列である.今回は ${ }_{W}^{C} \mathbf{T}$ と ${ }_{T}^{S} \mathbf{T}$ 単位行列と仮定し, センサ座標系から CT 座標系への変換行列を以下の手順により求める.

(1)気管支ファントム表面上の特徽的な $n$ 点を選び, それらの点におけるセンサの出力座標值を記録

(2)手順(1)で取得した点に対応する CT 像上の座標 を記録

上記(1), (2)で用いる特徵点は, CT 像と気管支ファン トムの形状から対応の取れる点を目視により設定し た. 上記 $n$ 点の対応を用いて，最小二乗法の解析的 解法[2]により位置合わせ誤差 $\left(=\left\|{ }^{C} \mathbf{p}-\left({ }_{S}^{W} \mathbf{R}^{T} \mathbf{p}+{ }^{W} \mathbf{t}_{S}\right)\right\|^{2}\right)$ を最小とする ${ }_{S}^{W} \mathbf{R}{ }^{W} \mathbf{t}_{S}$ を計算する.

\section{3. 実験と考察}

気管支ファントム 1 例に対して本手法を適用した. CT 画像のスライス内画素数は $512 \times 512$ pixels，スラ イス枚数は 361 枚，スライス内画素サイズは $0.684 \mathrm{~mm}$ ，スライス厚は $0.625 \mathrm{~mm}$ ，再構成間隔は $0.5 \mathrm{~mm}$ である。磁気式位置センサは Northern Digital 社製 Aurora を用いた。位置センサのコイルは直径 $0.8 \mathrm{~mm}$, 長さ $8 \mathrm{~mm}$, 重さ $0.7 \mathrm{~g}$ であり, 長さ $2 \mathrm{~m}$ の軟 性コードの先端付近内部に固定されている. Aurora の測定可能空間は $500 \mathrm{~mm} \times 500 \mathrm{~mm} \times 500 \mathrm{~mm}$ であり， 小型・磁気式・軟性という点から，人体内部でも測 定可能と考えられる. 位置合わせの基準点の数は $n=6$ とした。

\section{(a)位置センサ静止実験}

まず，位置センサの精度を評価する一つの指針と して，静止した位置センサにおける位置情報の時間 変動を測定した。磁場発生装置の周囲 $1 \mathrm{~m}$ 以内には 磁場の妨げとなる金属を配置せず，計算機までの距 離は約 $2 \mathrm{~m}$, 磁場発生装置からセンサまでの距離は約 $200 \mathrm{~mm}$ とした。 Table 1 に，測定間隔 1 秒，測定回 数 600 回で位置情報を取得した時の，サンプル点の 各軸座標值に対する標準偏差を示す。センサのみの 場合と，センサを内視鏡内部に挿入した場合につい て測定を行ったが，静止条件における時間変動は両 者の場合共に小さいため, 内視鏡ナビゲーションシ ステムへの応用が十分可能であると考えられる.

\section{(b)位置合わせ精度}

磁気センサと CT 像の座標系の位置合わせ精度を Fiducial Registration Error (FRE)で評価した。 FREは 次式で定義され，位置合わせに用いた基準点同士の 対応精度を評価する值である。

$$
\mathrm{FRE}=\left\|\frac{1}{n} \sum_{i=1}^{n}\left\{{ }^{C} \mathbf{p}-\left({ }_{S}{ }_{S} \mathbf{R}^{T} \mathbf{p}+{ }^{W} \mathbf{t}_{S}\right)\right\}^{2}\right\|
$$

実験の結果，FRE は $1.53 \mathrm{~mm}$ であった. FREによる 評価に加え， Target Registration Error (TRE)を用いた 位置合わせ精度についても評価を行う必要があると
考えられる.

\section{(c)位置合わせ結果}

本手法による磁気センサと CT 像の座標系の位置 合わせ結果の一例を Fig.1 に示す. Fig.1 上段に推定 位置を含む Axial, Sagittal, Coronalの各断面像を示 す. 2 直線が直交している各図の中心が推定位置を 表す. Fig.1 下段に推定対象となる実内視鏡像を示す. 実験の結果, 内視鏡のおおまかな観察位置を各断面 像上でリアルタイムに提示可能であることを確認し た. 今後は, 観察位置に対応した 3 次元表示が可能 な内視鏡ナビゲーションシステムを開発する予定で ある。

\section{4.むすび}

磁気センサと CT 像の座標系の位置合わせ実験を 行い, 内視鏡のおおまかな観察位置を CT 像上でリ アルタイムに提示可能であることを確認した。今後 の課題として，センサキャリブレーション行列取得 法の開発，画像間類似度と位置センサ情報を利用し た内視鏡動き推定手法の開発などが挙げられる。

謝辞 日頃討論頂く名古屋大学末永研究室諸氏に感謝寸 る. 本研究の一部は, 文部科学省・日本学術振興会科学研 究費補助金，21 世紀 COE プログラム「社会情報基盤のた めの音声映像の知的統合」, ならびに厚生労働省がん研究 助成金によった.

\section{参考文献}

[1] 出口大輔ら, “イメージレジストレーションと動き予 測を利用した気管支鏡動き推定精度向上に関する検討,” 電子情報通信学会技術報告, MI2003-88, pp.77-82, 2004

[2] Berthold K. P. Horn, "Closed-form solution of absolute orientation using unit quaternions," Journal of the Optical Society of America A, Vol.4, pp.629-642, 1987

Table 1 Standard deviation of position data outputted from the positional sensor

\begin{tabular}{|c|c|c|c|c|c|}
\hline $\begin{array}{c}\text { Measuring } \\
\text { status }\end{array}$ & Axis & S.D. $(\mathrm{mm})$ & $\begin{array}{l}\text { Measuring } \\
\text { status }\end{array}$ & Axis & S.D. $(\mathrm{mm})$ \\
\hline \multirow{3}{*}{$\begin{array}{l}\text { sensor } \\
\text { only }\end{array}$} & $x$ & 0.043 & \multirow{3}{*}{$\begin{array}{c}\text { inside } \\
\text { bronchoscope }\end{array}$} & $\mathrm{X}$ & 0.055 \\
\hline & $y$ & 0.0 & & $y$ & \\
\hline & $z$ & 0.011 & & z & 0.008 \\
\hline
\end{tabular}
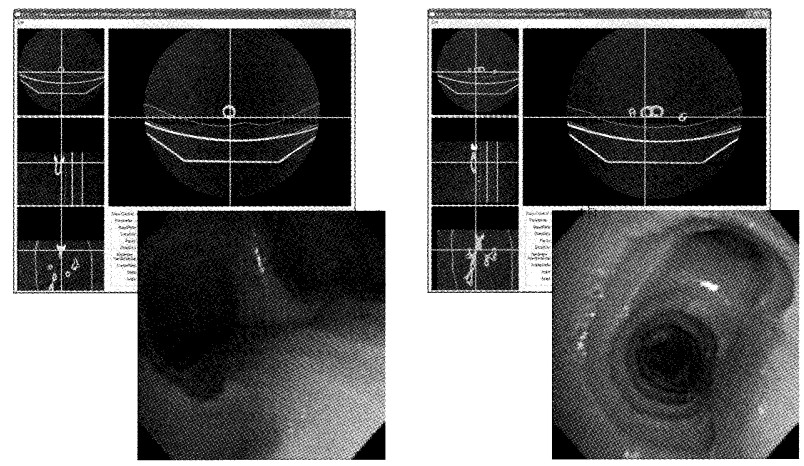

Fig.1 Estimation results: Top images show estimated positions of the bronchoscope on a 3D X-ray CT image. Bottom images show real endoscopic images. 


\title{
04(XII)-93 モバイル C-arm CT によるボリュームデータを用いた 術中ナビゲーションシステム \\ 林部充宏 ${ }^{\mathrm{a}}$, 鈴木直樹 ${ }^{\mathrm{a}}$, 服部麻木 ${ }^{\mathrm{a}}$, 大竹義人 ${ }^{\mathrm{a}}$, 鈴木董之 ${ }^{\mathrm{a}}$, 小林進 ${ }^{\mathrm{b}}$, 篠田明彦 ${ }^{\mathrm{c}}$, 二八宮邦稔 ${ }^{\mathrm{C}}$ \\ a 東京慈恵会医科大学高次元医用画像工学研究所, ${ }^{b}$ 東京慈恵会医科大学. 外科学講座, c 東京慈恵会医科大学形成外科学講座
}

Intraoperative navigation system with volume data of mobile C-arm CT Mitsuhiro Hayashibe ${ }^{a}$, Naoki Suzuki ${ }^{a}$, Asaki Hattori ${ }^{a}$, Yoshito Otake ${ }^{a}$, Shigeyuki Suzuki ${ }^{a}$ Susumu Kobayashi ${ }^{\mathrm{b}}$, Akihiko Shinodac, Kunitoshi Ninomiya ${ }^{\mathrm{c}}$

a Inst. for High Dimensional Medical Imaging, Jikei Univ. School of Med., Tokyo, Japan

${ }^{\mathrm{b}}$ Dept. of Surgery, Jikei Univ. School of Med., Tokyo, Japan

Dept.of Plastic Surgery, Jikei Univ. School of Med., Tokyo, Japan

\begin{abstract}
We have constructed a high-tech navigation operating room that has enabled us to develop new surgical procedures and to examine our various image-guided surgery systems and robotic surgery devices through clinical testing. In this operating room a mobile C-arm CT (Siemens) and an operating table made of carbon fiber material (MAQUET) are equipped to be used for intraoperative patient inner structure data acquisition. We have been developing several techniques or algorithms which are essential for this data fusion system. In this study, we focused on a volumetric navigation system using intraoperative $\mathrm{C}$-arm CT data. The 3D volumetric data is directly displayed on the monitor with video images of the surgical field using a 3D optical tracking system, a ceiling-mounted articulating monitor and a small size video camera mounted on the back of the monitor. The performance of this system was validated by an experiment in the operating room.
\end{abstract}

Key words: Image guided surgery, mobile C-arm CT, Volumetric visualization

\section{1. はじめに}

こ秃までに高次元医用画像技術老活用し, 新し い治療法の臨床研究を行うことのできる設備を有す るハイテクナビゲーション手術室(Fig.1)の建設を行 い前回本学会にて報告した. またわれわれは術中 支援を目的としたナビゲーションシステムのひとつと して術者の視野の実空間内に仮想空間上の臟器 内部の三次元構造を提示し, 内部を透玑て見るよ うな感覚で手術を行うためのData Fusion システム の開発を行ってきた. 本稿では術中に手術室内で 獲得した CT データセットを用い, これを術野画像上 に Volume Rendering することで直接的に対象部位 の内部構造を提示可能な手術ナビゲーションシステ ムについて報告する。

\section{2. システム構成}

Fig. 2 に本システムの構成を示す. 本手術室内で はモバイル C-arm CT (SIREMOBILE Iso-C ${ }^{3 D}$ Siemens) と CT による計測を妨げない電動式ハメ タル手術台 (VIWAS, MAQUET)により術中に患部 の三次元構造を得ることができる. 1 回 2 分間のスキ

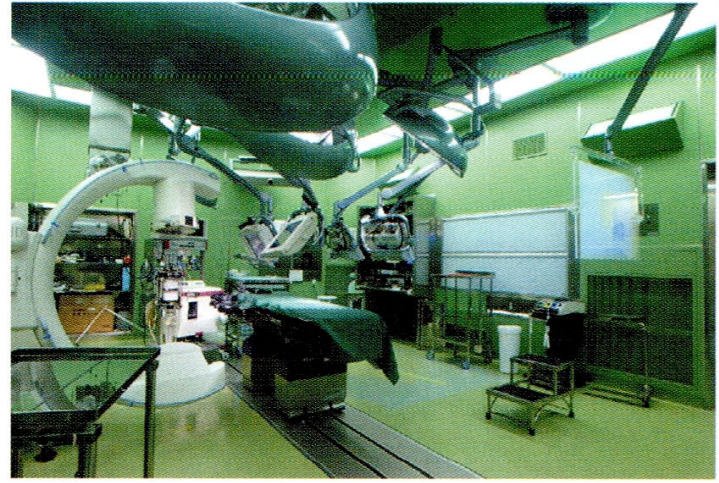

Fig. 1 High-tech navigation operating room Mobile C-arm CT is shown in the left of this image.

ヤンで $12 \mathrm{~cm}^{3}$ にあたる $3 \mathrm{D}$ データ収集を行う. 通常付 属のモニタトロリで断層画像を雄認するが, 本研究 では直接的に術野画像上での Volume Rendering により内部を透かし見るような感覚で手術を行うため のData Fusion システムを開発した. Fig.2 に示寸よ うに手術室天井面に組み込む形で設置した術者視 野用アーム型モニタおよび光学式三次元位置セン サ (Optotrak, Northern Digital)を用いることで術中 の Volume Dataの位置およびモニ夕の視線方向の 


\title{
04(XII)-94リアルタイム臓器トラッキングの術中 MRI システムヘの実装
}

$\bigcirc$ 徳田 淳一 ${ }^{a}$, 森川茂廣 ${ }^{b}$, 出村公一 ${ }^{c}$, 佐藤浩一郎 ${ }^{c}$, Hasnine A Haque ${ }^{d}$, 平野勝也 ${ }^{d}$, 塚元鉄二 ${ }^{d}$, 土肥 健純 ${ }^{a}$, 波多 伸彦 ${ }^{a}$

$a$ 東京大学大学院 情報理工学系研究科, ${ }^{b}$ 滋賀医科大学 MR 医学総合研究センター, ${ }^{c}$ 滋賀医科大学 外科学講座, ${ }^{d} \mathrm{GE}$ 横河メディカルシステム株式会社

\section{Implementation of Real-Time Organ Tracking for Intraoprative MRI \\ Junichi Tokuda ${ }^{a}$, Shigehiro Morikawa ${ }^{b}$, Koichi Demura ${ }^{c}$, \\ Koichiro Sato $^{c}$, Hasnine A Haque ${ }^{d}$, Masaya Hirano ${ }^{d}$, \\ Tetsuji Tsukamoto ${ }^{d}$, Takeyoshi Dohi ${ }^{a}$, Nobuhiko Hata ${ }^{a}$ \\ ${ }^{a}$ Graduate School of Information Science and Technology, The University of Tokyo \\ ${ }^{b}$ Biomdical MR Science Center and ${ }^{c}$ Department. of Surgery, Shiga University of Medical Science \\ ${ }^{d}$ GE Yokogawa Medical Systems}

\begin{abstract}
We developed a navigator-echo-based real-time organ motion tracking system integrated with a 0.5Tesla open-configured clinical MRI system for intervention. A pulse sequence to acquire magnetic resonance echo signals for both imaging and motion tracking enables to measure displacements of an organ during imaging. The time resolution of the tracking is maximum $8.3 \mathrm{~Hz}$ per direction, which depends on imaging parameters. At the same time, on-the-fly echo processing framework minimized the delay of outputting tracking result from actual motion. Real-time tracking of a moving phantom and a moving liver of breathing volunteer were demonstrated with enough speed. In conclusion, the proposed system can provide real-time motion information of a target organ during surgery, and has a potential to control therapeutic devices, such as focused ultrasound transducer, to track moving target.
\end{abstract}

Key Words: MRI-guided surgery, Motion tracking, Navigator Echo

\section{1. はじめに}

磁気共鳴画像 (MRI) 誘導手術は，撮像，患部位置の 特定，穿刺のガイダンスいたるまで，全てが統一された MRI 装置の座標系の管理下にあり，極めて正確な夕ー ゲッティングを可能にしている，その反面，MRI は画像 の時間分解能やモーション・アーチファクトなどの問題 で撮像対象の動きに弱い. 呼吸などによる臓器の動きが 存在すると, 画像が実際の臓器の動きに追従しきれず, 正確な患部の位置情報をリアルタイムに提供できない.

そこで筆者らは navigator echo[1] による術中臓器卜 ラッキングを提案してきた $[2]$. 本研究では手術用開 放型 MRI 装置 GE Signa SP/i 0.5T (GE Healthcare, Chalfont St. Giles, United Kingdom) に提案手法を害 装したので報告する。具体的には，(1) すべてのエコー デー夕を蓄積せずに逐次デー夕処理プロセスへ転送する ことによって遅延を抑え，(2) navigator echoにより高 い時間分解能で物体の変位を計測した上で，(3) 得られ た物体の変位を元に術中画像データのモーションアーチ ファクトの補正, 及び術中画像や高画質術前画像の位置 あわせを行う。

\section{2. 方法}

\section{$2 \cdot 1$ パルスシーケンス}

Navigator echo は単一の MR 信号で撮像対象の動き を推定する手法である。一般的な MRI の撮像では，MR 信号の収集を数十〜数百 $\mathrm{ms}$ 間隔で数百回繰り返す必要 があるのに対し, navigator echoは一回の収集で動きに 関する情報を取り出すことができる。本研究では術中に 利用される FGREシーケンスを元に，画像撮像とトラッ キングを同時に行うシーケンスを開発した (Fig. 1). 本シーケンスでは, 撮像断面内の各軸方向の並進運動を 検出する 2 種類の navigator を, 通常の画像構築のため の信号収集の繰り返しに交互に挿入している。1枚の画 像撮像の間に各方向に 64 回の並進移動量検出を行い, 繰り返し時間パラメータ $T R$ に対して一枚あたりの撮 像時間は $T R \times 256$, 一方向の位置検出の時間分解能は $1 /(T R \times 4)$ となる.

\section{$2 \cdot 2$ リアルタイムエコー処理システム}

撮像対象の実際の動きから, 動きの情報が提示される までの遅延を最小限に抑えるため，コイルから受信した MR 信号を量子化直後に処理する必要がある。本研究 


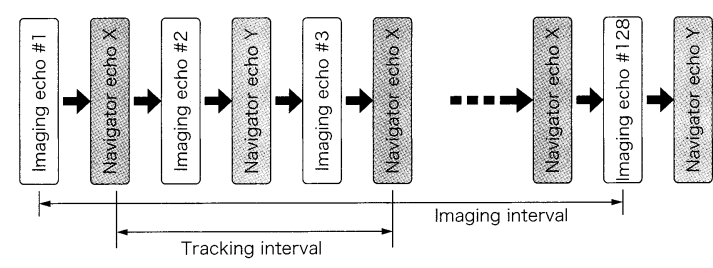

Fig.1 Sequence to obtain MR signal for image and tracking.

では MRI システムのハードウェアで実行されるパルス シーケンスから信号収集のタイミングをとりだし，バッ ファメモリに格納された MR 信号データを直接読み出す ソフトウェアを新たに開発した。読み出された MR 信号 デー夕は，Ethernet を介してシステムに接続されたパー ソナルコンピュータへ転送されて処理される。処理は受 信データの種類によって切り替えられ, navigator echo の場合は移動量検出, 撮像対象物の現在位置情報の更新, および位置情報に基づいた画像の位置合わせを行う。

方，画像構成用データの場合は現在位置の情報を元に信 号に補正をかけて出力画像のアーチファクトの低減を図 る。これにより，動きによるアーチファクトを低滅した 画像を，数十ミリ秒程度の間隔で最新の位置情報を付加 して術者に提示することが可能となる。すなわち第 1 節 の $(1)$ (3) が実現される.

\section{$2 \cdot 3$ 手術ナビゲーションソフトウェアとの連携}

手術ナビゲーションソフトウェア 3D Slicer に拡張モ ジュールを追加し，前節の MR 信号の処理系からソケッ 卜通信でトラッキング情報を取得できるようにした。こ れにより, あらかじめ撮像しておいた臟器のボリューム 画像や，ボリューム画像から構築して扔いたサーフェス データなどを術中にリアルタイムに実際の位置に位置合 わせして表示することができる $(2)$.

\section{3. 実験}

本研究で実装した手法の有用性を評価するため，マグ ネット内でファントムを動かしながら撮像を行い，リア ルタイムトラッキングとそれに基づく画像補正および 位置あわせの効果を観察した。その結果，ファントムが 動いても輪郭のくっきりしたファントムの画像を出力で き，ファントムの位置を確実に画像で捕らえることがで きた (Fig.3,). 尚, マグネット内のカメラ映像とトラッ キング結果の出力を比較したところ，ファントムの動き がトラッキング結果に反映されるのはビデオ画像約 2 フ レーム分程度 (約 $60 \mathrm{~ms}$ ) であった。また今回の撮像は TR:30ms で行っており, トラッキングの時間分解能は $8.3 \mathrm{~Hz}$ であった.

また，臨床と同様の条件で健常なボランティアの肝臓 をサジタル断面で撮像し，呼吸時の肝臓の動きをリアル タイムにプロットした。マブネット内に設置されたカメ ラ画像から観察される呼吸に伴う腹部の動きとプロット 結果から, 本手法により，呼吸に合わせて肝臓の移動量

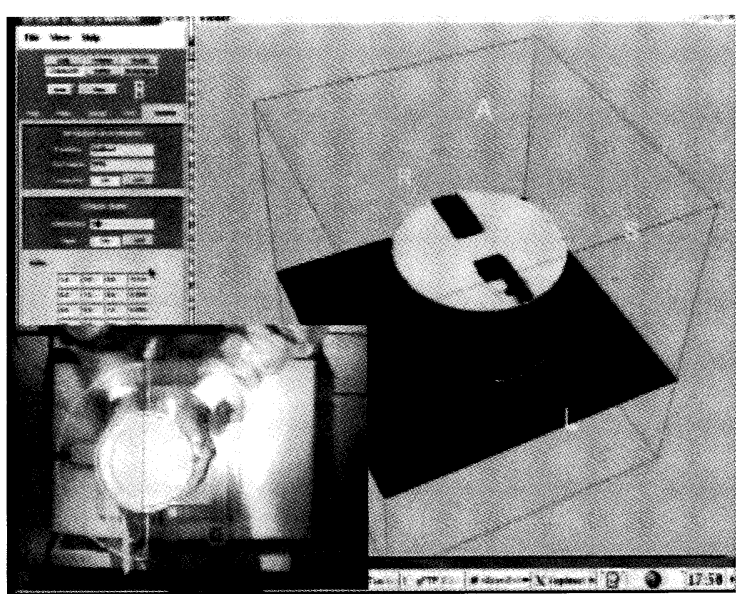

Fig.2 Surgical navigation software "3D Slicer" receives tracking information and shift a volume or a surface model to current position.

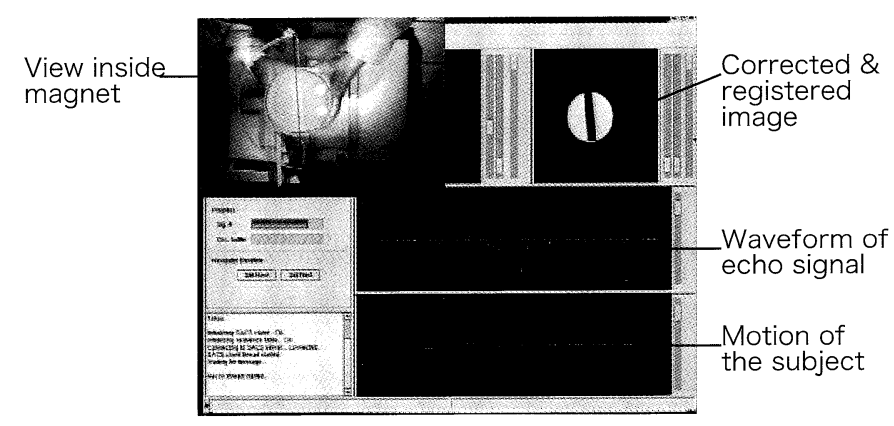

Fig.3 A screenshot of the echo processing software during tracking of the moving phantom.

を提示できることが確認できた。

\section{4. 考察・結語}

以上の結果より, 本システムは動いている臓器を対象 とした手術の誘導への有用性が示された。特に, 肝臟な ぞを対象とした MRI ガイド下収束超音波での焦点位置 の制御に用いることで, 動いている臟器に追従しながら 治療を行うといったことが可能になると考元られる。

この研究の一部は学術振興会特別研究員制度より支援 を受けている。

\section{参考文献}

[1] R. L. Ehman et.al., "Adaptive Technique for High Definition-MR Imaging of Moving Structures Navigator Echoes", Radiology, 173:255-263, 1989.

[2] J. Tokuda, et.al., Integration of Projection Profile Matching into Clinical MR Scanner System for Realtime Organ Tracking and Image Registration, in Proc. MICCAI 2003, LNCS 2879, pp.311-318, 2003. 
04(XII)-95Ｄiffusion Tensor Tractography に基づくニューロナビゲーションの

術中 Fiber Stimulation による検証および術中 Fiber Tracking 可 能なナビゲーションシステムの開発

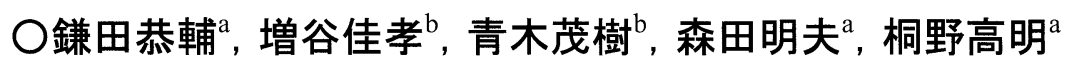

${ }^{\mathrm{a}}$ 東京大学 医学部附属病院 脳神経外科, ${ }^{b}$ 同 放射線科

Intra-Operative Fiber Stimulation for Validation of Neuronavigation based on Diffusion Tensor Tractography and Development of Navigation System with Intra-Operative Fiber Tracking Function

K. Kamada ${ }^{\mathrm{a}}$, Y. Masutani ${ }^{\mathrm{b}}, \mathrm{S}$. Aoki, $\mathrm{S}^{\mathrm{b}}$. A Morita ${ }^{\mathrm{a}}$, T Kirino ${ }^{\mathrm{a}}$

a Department of Neurosurgery, The University of Tokyo Hospital, Tokyo, Japan

${ }^{\mathrm{b}}$ Department of Radiology, The University of Tokyo Hospital, Tokyo, Japan

\begin{abstract}
In order for better surgical planning and combination of neurolophysiological monitoring, we developed a new neuronavigation system, which enabled to perform diffusion tensor-based tractography during operation and to display different image data sets such as anatomical three-dimensional MRI (3DMRI), FA and fiber orientation colormnap data. Intraoperative direct fiber stimulation was used to evoke the motor responses to confirm the accuracy of the corticospinal tract (CST) depicted on this system. Intraoperative calculation of DTI-based tractography information on the neuronavigation system allowed display of spatial relationships between lesions and the CST, leading to avoidance of tract injury during lesion resection. Direct fiber stimulation was used for a real-time, reliable white matter mapping, which functioned to adjust the discrepancy between the neuronavigation system and potentially shifted positions of the brain structures. The combination of these techniques enabled us to identify accurate positions of the CST during surgery and to accomplish optimal tumor resections.
\end{abstract}

Key words: Diffusion tensor imaging, Neusonavigation, Tractography

\section{1. はじめに}

脳神経外科手術は, 病変とその切除範囲, 重要 な脳機能の位置関係を正確に把握することで治療 方針が決定する. 現在, 術野の位置を正確に捉え るためには, 3 次元 T1 強調画像(3DMRI)を用いた 解剖学的ニューロナビゲーションが広く普及してい る. 一方で, 拡散強調画像による敛軸索画像や機 能 MRI による脳皮質マッピングなどの脳機能画像 が臨床応用され，手術計画や手術ナビゲーション への応用報告がされ始めた. また, 術中画像による Fiber Tracking の試みも報告されているが, 低磁場 MRI の使用に起因する画質の劣化のため, 手術ナ ビゲーションに有用な情報は得られていない.

我々は diffusion tensor imaging (DTI)による fiber tracking をはじめ, 機能 MRI などの異なる機 能画像情報を表示することが可能なニューロナビゲ ーション装置を開発しており, 2003 年 10 月より 10 例以上の臨床応用を行っている. 本稿では, その 臨床における有用性, および本装置で表示された tractography の結果を白質線維束電気刺激(fiber stimulation)による検証について報告する.

\section{2. 方法}

我々の開発したシステムは2つのタイプがあり, 一方は, 市販のナビゲーションシステム (Medtronic 社製Stealthstation)に基づくType Iであり，もう一方 は, passive typeの光学式トラッキング装置(NDI社 製Polaris accedo)とフリーウェア“VOLUME- ONE “を用いて開発したType IIである. いずれも場合も, 東大放射線科で開発したDTI解析プログラム” diffusion TENSOR Visualizer: dTV ${ }^{\prime 1)}$ による結果 を使用する.

前者では, dTV により DICOM データとして export された解析結果を使用するため, DICOM デ 一タを import 可能ないかなるシステムでも使用でき る利点がある. 一方, 後者は VOLUME-ONE にプ ローブの位置が常にフィードバックされるため, Fiber Tracking をはじめとする, 術中の患者座標で の種々の処理が可能となり, 電気刺激位置と fiber 位置の相関を観察する上で, より有利となる.

後者のシステムのソフトウェアは, 表 示部 (VOLUME-ONE 1.64 改), センサ受信部, および 解析部 (dTV.II R 2b) から成る. 使用したPC 
Workstationは, インテルXeonプロセッサ $3 \mathrm{GHz}$, 4Gb RAMとNVIDIA社製Quadro FX 3400 のグラフ イックスカードを搭載したもので, Windows XP professional環境下で稼動する. また, 解剖画像と DTIのレジストレーションは, グラフィクスハードウェ アを利用した高速な手法 ${ }^{2)}$ で行った。

Fiber stimulation は $2 \mathrm{msec}$ 幅の 5 train の monopolar 電気刺激を用い, 手掌, 足底筋群からの筋電 図を導出することでMotor evoked Potentials (MEP) を記録した。

MRI データは, GE 社製 $1.5 \mathrm{~T}$ MRI を使用し, 3DMRI (T1 強調像) と13軸の MPG を印加したDTI を取得した。

\section{3. 結果と考察}

我々のシステムでは, 画面上の任意の関心領域 から異方向性のあるボクセルを選択することで数秒 程度で fiber tracking が可能であり, 皮質春髄路, 視放線をはじめとする重要な皮質下線維連絡が tractography として表示され，ナビゲーションに使用 できた.また, fiber tracking 結果をボクセル化し, 3DMRI に重畳して3次元立体画像表示することも 可能とした(Fig. 1). また, Type II では, 切除部位と tractography として表示された領域の3次元的な距 離計測が可能であり, 距離に基づく警告機能を実 装した. また VOLUME-ONE のマルチチャンネル表 示機能を利用して, 解剖画像, fiber tracking 結果, FA 画像, ADC 画像, Fiber 方向カラーマップなどを 瞬時に切り替えることが可能で, 有用であった.

現在までの検討では, fiber stimulation部位と皮 質脊髄路が約 $1 \mathrm{~cm}$ 以内に近接した時にMEPが検 出されることが確認されている ${ }^{3)}$. ナビゲーション画 面 (Type I) と電気刺激の結果をFig. 2，3に示す. 我 々のシステムでは, トラッキング装置の精度 RMS で $0.4 \mathrm{~mm}$ 程度であるため, 今回の結果はbrain shift などの誤差要因を含んでいると考えられる.

このように, Tractography による視覚的なナビゲ 一ション情報と電気刺激による brain shiftに依存し ない機能的なナビゲーション情報は, 相互に補完し あう関係にあり，併用することで更に信頼性の高い 手術ナビゲーションが実現されると考えられる.

\section{4. まとめ}

我々の開発したシステムは, 術中 fiber tracking を始め, 従来のナビゲーション装置にない機能を有 しており, その有用性が確認された. また, 電気刺 激を併用することにより, 脳機能を温存した手術が より高精度で実現されることが示唆された。

\section{文献}

1) Masutani Y, et al: Eur J Radiol 46:53-66, 2003

2) Masutani $Y$, et al., Proc. CARS, pp 1315, 2003

3) Kamada K, et al: Surg Neurol 59:352-361; discussion 361-352, 2003

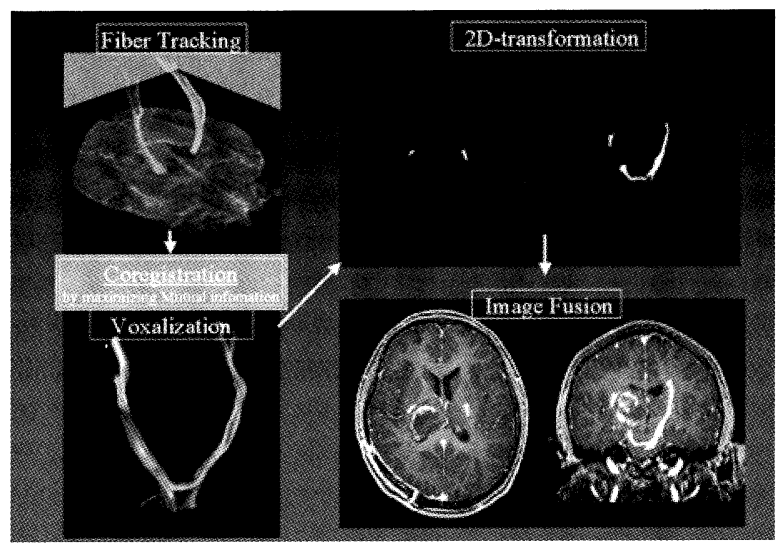

Fig.1 Image fusion of 3MRI and DTI data

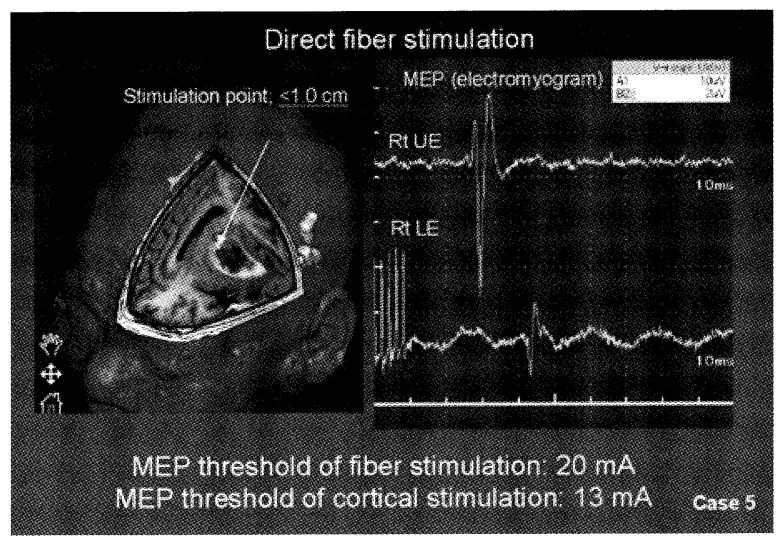

Fig.2 Navigation \& fiber stimulation; case 5

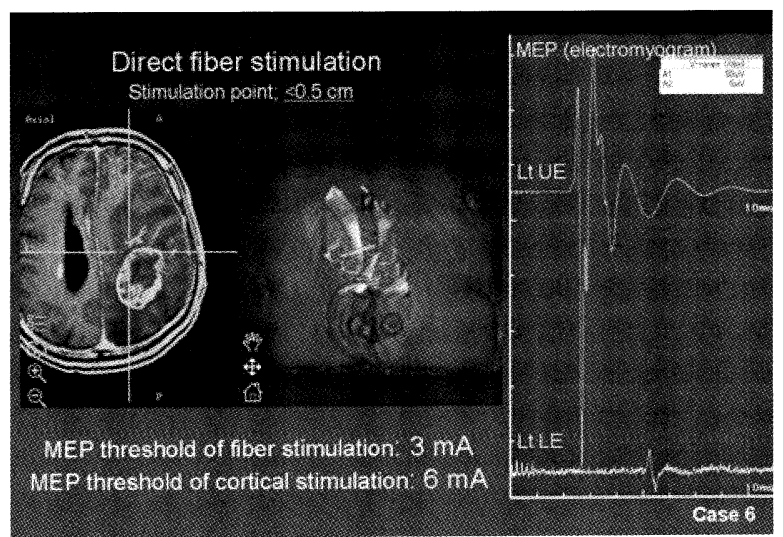

Fig.3 Navigation \& fiber stimulation; case6 


\section{4(XII)-96}

\section{術中拡散強調画像 (DWI) ナビゲーションシステム \\ ○小澤 紀彦 ${ }^{a, b}$, 村垣 善浩 ${ }^{a, c}$, 白川 洋 ${ }^{b}$, 鈴川 浩一 ${ }^{d}$, 中村 亮一 ${ }^{a}$, 伊関} 洋 ${ }^{a, c}$

${ }^{\mathrm{a}}$ 東京女子医科大学大学院先端生命医科学系専攻先端工学外科学分野, ${ }^{b}$ (株) 日立义 ディコ MRI システム本部, ${ }^{\mathrm{c}}$ 東京女子医科大学脳神経センター脳神経外科

\section{Navigation System using Intraoperative Diffusion Weighted Imaging}

N.Ozawa ${ }^{\mathrm{a}, \mathrm{b}}$, Y.Muragakia ${ }^{\mathrm{a}, \mathrm{c}}$, H.Shirakawa ${ }^{\mathrm{b}}$, H.Suzukawa ${ }^{\mathrm{d}}$, R.Nakamura ${ }^{\mathrm{a}}$, and H.Iseki ${ }^{\mathrm{a}, \mathrm{c}}$

${ }^{a}$ Faculty of Advanced techno-surgery(FATS) Institute of advanced Biomedical

Engineering \& Science(ABME\&S) Graduate school of Medicine (R\&D) Tokyo Women's

Medical University, Tokyo, Japan

${ }^{\mathrm{b}}$ MRI system Division, Hitachi Medical co , Chiba, Japan

${ }^{\mathrm{c}}$ Dept. of Neurosurgery, Neurological Institute(Clinicaldivision) Tokyo Women's

Medical University, Tokyo, Japan

${ }^{\mathrm{d}}$ Infocom co., Tokyo, Japan

Abstract: In surgical removal of a malignant brain tumor which is close to a pyramidal tract, diffusion tensor images obtained by preoperative magnetic resonance imaging (MRI) can display the spatial relationship between the tumor and the pyramidal tract. This image, however, is not appropriate to navigate the surgery because of brain shift due to surgical manipulation. We developed a navigation system using intraoperative diffusion weighted imaging (DWI) by open MRI, which is the first trial with a $0.3 \mathrm{~T}$ scanner to aim at visualization of pyramidal tract. A newly developed surgical coil has both functions of head fixation in surgery and a receiver coil in scan. The DWI of volunteers could display nerve fibers such as pyramidal tracts under the optimized scan parameters. By refining navigation software, a physical position directed by the pointing device could be displayed correctly on 3 cross-sectional T1 (or T2) weighted images and three-dimensional (3D) DWI. Initial clinical evaluation of this system revealed that the spatial relationship between the tumor, the pyramidal tract, and the treatment position could be displayed correctly. Furthermore the surgeons could recognize these positions intraoperatively and visually. The navigation system using intraoperative DWI for a tumor and nerve fibers helped the surgeons remove the tumor and obviated postoperative disturbance such as motor paralysis.

Keywords: intraoperative mri, diffusion weighted imaging, navigation

\section{1. 背景·目的}

悪性脳腫瘍摘出手術では、腫瘍が錐体路 (運動 神経)近傍に存在するとき、如何に錐体路を損傷す ることなく腫瘍を最大限に摘出できるかが問題となる。 腫瘍と錐体路の位置関係を可視化するには、術前 の $1.5 \mathrm{~T}$ MRIにより神経線維束を描出する拡散テン ソル画像 ${ }^{1)}$ が参考となる。しかし、腫瘍摘出時には 脳が移動・変形する(ブレインシフト)ため、この画像 を元に手術ナビゲーションを行えば実際の位置とず れが生じる危険性が高い。したがって、術中に神経 線維束を画像化し、実際の位置を確認する必要が ある。
本研究の目的は、安全な手術を行うため術中に 錐体路を可視化し、正確な位置情報を示すことで ある。そのために、オープン MRI による術中拡散強 調画像 (DWI) ナビゲーションシステムを開発した。

\section{2. 方法}

$$
\text { オープン MRI（日立メディコ AIRIS II }{ }^{\circledR} 0.3 \mathrm{~T} \text { ) とナ }
$$
ビゲーションシステム (NDI 社 Polaris $\left.{ }^{\circledR}\right)$ を備えた手 術室で、実験及び臨床評価を行った。具体的に は、

（1）健常ボランティアを対象として、診断用 QD ヘッ ドコイルを用いて撮影条件を最適化し、DWI 画 像の画質を $\mathrm{T} 1 \mathrm{~W}$ 画像と比較評価した。 
（2）術中に頭部固定及びDWI 撮影が可能なコイル を新規に開発した。このコイルで術中に撮影し た DWI 画像を T1W 画像と比較評価した。

（3）DWI 画像の表示 (Fig.1 右上)ができるようにナ ビゲーションソフトを改良し、術中 DWI 画像を用 いた手術ナビゲーションの臨床評価を行った。

\section{3. 結果}

（1）最適化した撮影条件を Table 1 に示す。ボラン ティアのDWI 画像は、Fig. 1 (右上)に示した通 り、錐体路が明瞭に描出された。

Table1 Typical MR imaging parameters of EPI sequence for diffusion weighted imaging with peripheral gating (heart rate 70)

\begin{tabular}{|c|c|c|c|c|}
\hline $\begin{array}{c}\text { TR } \\
(\mathrm{msec})\end{array}$ & $\begin{array}{c}\text { TE } \\
(\mathrm{msec})\end{array}$ & $\begin{array}{c}\text { FOV } \\
(\mathrm{mm})\end{array}$ & $\begin{array}{c}\text { Scan } \\
\text { Matrix }\end{array}$ & $\begin{array}{c}\text { Recon. } \\
\text { Matrix }\end{array}$ \\
\hline $2571(* 1)$ & 111 & 250 & $100 \times 92$ & $256 \times 256$ \\
\hline
\end{tabular}

\begin{tabular}{|c|c|c|c|c|}
\hline $\begin{array}{c}\text { Thick. } \\
(\mathrm{mm})\end{array}$ & NEX & $\mathrm{b}\left(\mathrm{s} / \mathrm{mm}^{2}\right)$ & $\begin{array}{c}\text { MPG } \\
\text { axis }\end{array}$ & Scan Time \\
\hline 8 & 8 & 700 & A-P & $\begin{array}{c}1 ' 22 " \times 3 \\
(* 1)\end{array}$ \\
\hline
\end{tabular}

(*1) depending on pulse rate.

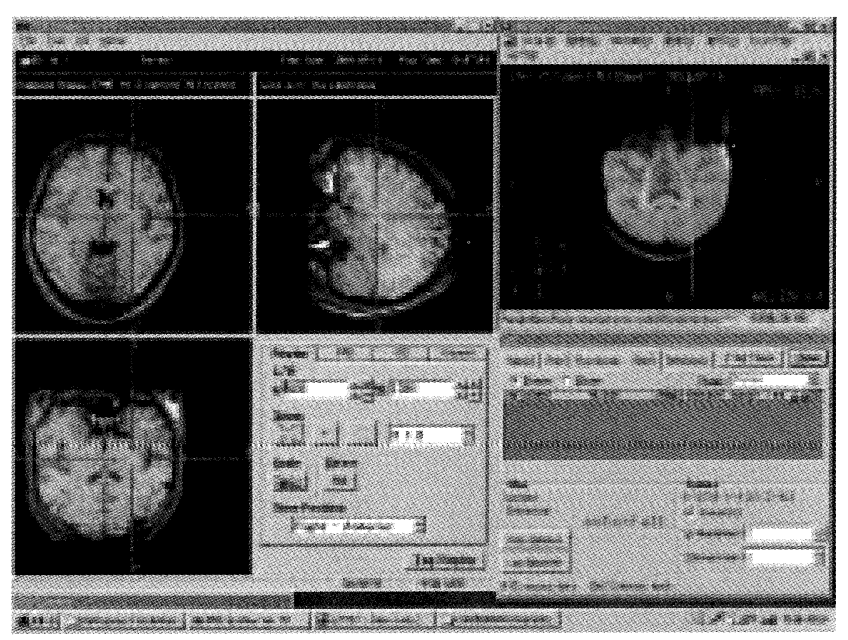

Fig. 1 Diffusion weighted imaging navigation

(Volunteer image).
（2）新規に開発したコイルは、術中に頭部固定及 びDWI撮影が可能だった。術中 DWI画像は、 錐体路を明瞭に描出した。但し、頭部固定ピン 付近及び開頭部位ではややアーチファクトを生 じた。

（3）DWI 画像を用いた手術ナビゲーションは、術具 先端の位置を正確に画像上に表示することが できた。このナビゲーションを用いることによって、 $\operatorname{MEP}($ 運動誘発電位) により手足の運動神経に 関わると判断した領域が、腫瘍摘出腔と錐体路 を含む神経線維束の間にあることを確認した。

\section{4. 考察}

（1）DWI 画像で錐体路が明瞭に描出できたのは、 MPG(Motion Probing Gradient)パルスを A-P 方向に印加したため。また、DWI 画像の歪みが 少なかったのは、撮影条件で shot 数を 4 として 磁場不均一による影響を抑制したため。モーシ ヨンアーチファクトを抑制できたのは、脈派同期 計測としたため、と考えられる。

(2) 新規に開発したコイルは非金属のフレームを使 用したので、フレームに起因するアーチファクト は生じなかった。しかし、頭部固定ピンはチタン 製のためその付近にアーチファクトが生じた。ま た、開頭部位付近のアーチファクトは磁化率の 変化が大きいためと考えられる。

（3）DWI画像の視覚的な位置情報とMEPによる電 気生理学的な情報により運動神経に関わる領 域を保護しながら腫瘍を摘出することができた。

\section{結論}

術中拡散強調画像ナビ兮ーションシステムを開 発した結果、術中に錐体路を可視化し、正確な位 置情報を示すことができた。術者は錐体路を含む神 経線維束の位置を視覚的に把握できた。本システ ムは、手術の安全性向上に寄与する。

\section{文献}

1) Pajevic S, Pierpaoli C: Color schemes to represent the orientation of anisotropic tissues from diffusion tensor data: application to white matter fiber tract mapping in the human brain. Magn Reson Med 1999; 42: 526-54 


\title{
04(XII)-97 反射球マーカを用いた OpenMRI 下脳外科手術ナビゲーションシス テムの臨床応用
}

○武藤 俊介 ${ }^{a}$, 安藤 隼人 ${ }^{a}$, 長嶋 義昭 ${ }^{a}$, 植松 美幸 ${ }^{a}$, 鈴川 浩一 ${ }^{b}$, 中村 亮一 ${ }^{\mathrm{c}}$, 伊関 洋 ${ }^{\mathrm{c}}$, 村垣 善浩 ${ }^{\mathrm{c}}$, 梅津 光生 ${ }^{\mathrm{a}}$

a 早稲田大学大学院理工学研究科生命理工学専攻, ${ }^{b}$ インフオコム株式会社, ${ }^{\mathrm{c}}$ 東京女 子医科大学大学院先端生命医科学研究所先端工学外科分野

\section{Clinical application of the navigation system for the neurosurgery in the} intraoperative MRI-equipped operating theater using reflective ball markers

S.Muto a H. Ando ${ }^{\mathrm{a}}$, Y.Nagashima ${ }^{\mathrm{c}}$, M.Uematsuc ${ }^{\mathrm{c}}$, H. Suzukawa ${ }^{\mathrm{b}}$, R. Nakamura ${ }^{\mathrm{c}}$, H. Iseki ${ }^{\mathrm{c}}$, Y. Muragaki ${ }^{\mathrm{c}}, \mathrm{M} . \mathrm{Umezu}^{\mathrm{a}}$

${ }^{a}$ Dept.Integrative Bioscience and Biomedical Engineering, Waseda University.

b Infocom Co.Ltd. ' Faculty of Advanced Techno-Surgery, Institute of Advanced Biomedical Engineering \& Science, Tokyo Women's Medical University

\begin{abstract}
The navigation system has been designed for perfect extract of a brain tumor. It is believed that the system becomes more effective, if it is used in conjunction with Open MRI which is installed in an operation theater. In order to improve an accuracy of Navigation system as well as to reduce a preparation time, reflective ball markers were originally developed. First of all, in vitro test was performed using a head phantom model in which ball markers were installed in an accuracy position. It was found that both preparation time and accuracy were favorable results. Secondary, clinical trial with ball makers was carried out. It was indicated that preparation time was dramatically shorten by $70 \%$, whereas accuracy was not sufficient at the initial trial. Then, some analysis is required for the improvement of accuracy.
\end{abstract}

Key words: Reflective ball marker, Clinical, Navigation preparation time, Navigation accuracy

\section{1.はじめに}

悪性脳腫瘍摘出手術において、腫瘍の摘出率 は 5 年生存率に反映されるため、全摘出が求められ ている。本研究では、OpenMRI AIRIS II、日立メデ ィコ)を用いた脳神経外科手術用ナビゲーションシ ステムの機能性向上によって、機能温存下での腫 瘍全摘出を目標とする。

従来のナビゲーションシステムは、造影剤が封入 されたマーカを設置した患者頭部をMRI 撮影し、光 学式位置計測装置 (POLARIS OPTICAL TRACKING SYSTEM、Northern Digital Inc.) で認 識可能なポインタを用いてマーカを指すことによって、 患者上と画像上のマーカのレジストレーションを行っ ている。この際に問題となるのが、ポインタを操る人 の手振れ等の人為的誤差と、画像上のマーカ探索 が熟練者でなければ困難なことによる手術時間の 増加である。これらを改善するために反射球マーカ （Fig.1）を開発したところ、ファントムを用いた in vitro での精度評価実験では、Table1 に示すように精度
及び準備時間において従来マーカよりも優れた数 值を得ることができた ${ }^{122)}$ 。の結果より臨床での使 用が期待された。

本稿では、臨床に反射球マーカを使用し、従来 マーカとの比較を行った結果を報告する。

Tablel Comparison of effectiveness between two markers through in vitro experiment

\begin{tabular}{|c|c|c|}
\hline \hline & $\begin{array}{c}\text { Conventional } \\
\text { maker }\end{array}$ & $\begin{array}{c}\text { Reflective } \\
\text { ball marker }\end{array}$ \\
\hline $\begin{array}{c}\text { Average } \\
\text { error (mm) }\end{array}$ & 2.08 & 0.59 \\
\hline $\begin{array}{c}\text { Maximum } \\
\text { error (mm) }\end{array}$ & 3.30 & 1.53 \\
\hline $\begin{array}{c}\text { Preparation } \\
\text { time (sec) }\end{array}$ & 120 & 48 \\
\hline
\end{tabular}




\section{2. 方法}

ナビゲーションシステムを使用する際、マーカの 設置場所は患部付近の骨が最も適しているとされて いるが、現状の光学式位置計測装置は任意に配置 された反射球マーカを基準として認識することが出 来ない。そのため、 $\mathrm{T}$ 字形状の台座に、あらかじめ 位置関係が明確になっている反射球マーカを設置 し、それを患者開頭部近傍の皮膚に貼り付けること でナビゲーションを可能とした (Fig.1)。患部付近の 骨には従来のマーカを設置し、従来通りのナビゲー ションを行い、両者の準備時間及び精度に関して 比較する。

\section{3. 結果}

反射球マーカと従来のマーカを比較した結果を Table2 に示す。従来のマーカに関しては、操作する 人間の熟練度により計測誤差及び準備時間にばら つきがあるため、蓄積されたデータより平均的な值を 算出した。

\section{Conventional markers}

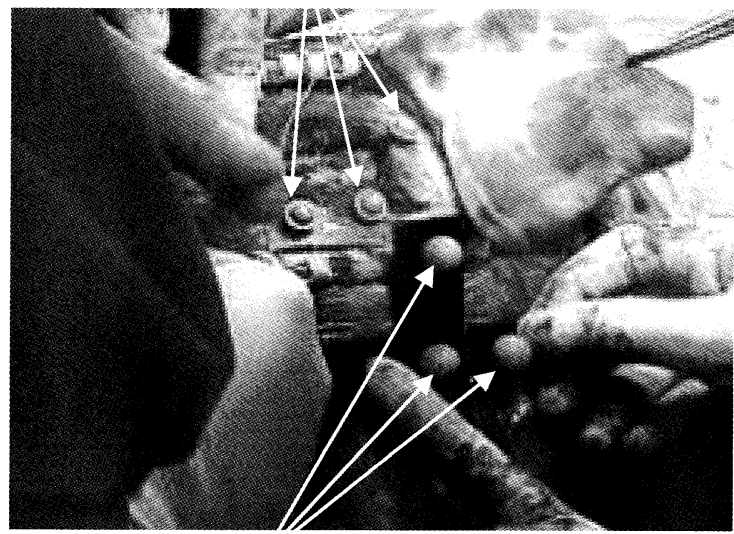

Reflective ball markers

Fig. 2 Two types of markers fixed onto the patient's head during neurosurgery

Table2 Comparison of effectiveness between two markers through clinical trial

\begin{tabular}{|c|c|c|}
\hline & $\begin{array}{c}\text { Conventional } \\
\text { marker }\end{array}$ & $\begin{array}{c}\text { Reflective } \\
\text { ball marker }\end{array}$ \\
\hline $\begin{array}{c}\text { Average } \\
\text { error(mm) }\end{array}$ & 1.28 & 2.32 \\
\hline $\begin{array}{c}\text { Maximum } \\
\text { error(mm) }\end{array}$ & 2.69 & 4.42 \\
\hline $\begin{array}{c}\text { Preparation } \\
\text { time(sec) }\end{array}$ & 360 & 120 \\
\hline
\end{tabular}

\section{4. 考察}

(1) 準備時間

in vitroでの評価と同様に、反射球マーカを用い た方が従来のマーカよりも短縮できることが確認され た。反射球マーカだけを in vitro と臨床で比較する と、臨床の方が約 60sec ほど多く時間がかかってい る。これは、MRI 画像上のマーカの探索にかかる時 間の差であり、in vitro ではマーカの位置があらかじ め予想が立つのに対し、臨床ではその場で確認す るしか方法がないからである。

(2) 誤差

反射球マーカの方が従来のマーカに比べて平均 で $1 \mathrm{~mm}$ 、最大で $1.5 \mathrm{~mm}$ 大きい結果となった。原因は、 基準マーカを皮膚にしか設置できなかったことにより、 皮膚の動きの影響を受けてしまったためと考えられ る。この誤差を解消するためには骨に反射球マーカ を設置すればよい。しかし、現在の光学式位置計測 装置はあらかじめ定まった位置関係の反射球しか 基準として使用できない。したがって、任意に配置し た反射球を基準として使用できるようにシステムを改 良することでその問題は改善されると考えられる。

\section{5. まとめと展 望}

反射球マーカを用いたナビゲーションシステムを 臨床に応用してみた結果、準備時間を大幅に短縮 することができた。その一方、誤差に関しては従来 のマーカを使った場合よりも大きな誤差となった。こ のシステムを実用化させるためには、誤差を改善し なくてはならず、そのためには、任意に配置された 反射球マーカを基準として認識させる必要がある。

謝辞: 本研究は文部科学省学術フロンティア研究 (01F-01)を使用して行われた。また、実験デー夕取 得には早稲田大学理工学部卒研究学生廣瀬佐智 雄君に謝意を表する。

\section{文献}

1) 長嶋義昭、鈴川浩一ほか: OpenMRI 下脳外 科手術におけるナビゲーションシステムの精度 及び操作性向上に関する研究 第 12 回日本 コンピュータ外科学会大会予稿集、2003

2) 長嶋義昭: OpenMRI下脳外科手術におけるナ ビゲーションシステムの精度及び操作性向上 に関する研究早稲田大学大学院理工学研 究科生命理工学専攻修士論文、2003 


\title{
固療法
}

○佐藤 浩一郎*、来見 良誠*、仲 成幸*、出村 公一*、谷 徹 * 森川 茂廣**、犬伏 俊郎**、Hasnine A Haque*** *滋賀医科大学 外科、 **MR 医学総合研究センター、***GE-横河 メディカルシステム

\section{A New display System for MR-Guided Microwave Ablation Therapy for The Liver Tumor \\ Koichiro Sato*, Yoshimasa Kurumi*, Shigeyuki Naka*,Koichi Demura*,Tohru Tani*, Shigehiro Morikawa**, Toshiro Inubushi**, Hasnine A Haque*** "Department of Surgery, and "'MR Research Center, Shiga Vniversity of Medical Science, Ohtsu, Japan, and ${ }^{* \star *}$ Graduate School of Information Science and Technology, The University of Tokyo, Tokyo, Japan、 ${ }^{\star * *}$ GE-Yokogawa Medical Systems, 4-7-127, Asahigaoka, Hino, Tokyo}

\begin{abstract}
Our research is aimed at enhancing the visual feedback to surgeon in MR-guided ablation for liver tumor to shorten the operation time, improve patient safety, and achieve cost savings in health care. We have already reported on MR-guided microwave thermocoagulation therapy of liver tumors ${ }^{1)}$ and have experienced more than 150 clinical cases. MR-guided microwave ablation of liver tumors, a minimally invasive surgery, has proven to be significantly less invasive to the patient. But in MR system, special skills of the surgeon are required to work in narrow body cavities with little space for the surgical tools. Navigation system for MR-guided ablation was developed providing 3D display of surgical tools relative to sensitive anatomical structures. In this study we present our clinical experiences with navigation system from the dataset at any orientation, as in multiplanar reformatting of an MRI volume.
\end{abstract}

Keywords: MR guided intervention, navigation surgery

\section{1、はじめに}

2000 年 1 月より我々は縦型オープン MRI を導入 し、MRガイド下で、肝腫瘍マイクロ波凝固療法 を中心にさまざまな手術やインターベンション 治療、および生検を行っている。リアルタイム MR ガイドインターベンションをより効果的に 施行できるように MR 装置に接続した PC に独自 のナビゲーションソフトウエア MR-navi を開発 し、MR 装置と組み合わせて術中画像支援として 臨床に応用している。この独自のナビゲーション ソフトウエアのさまざまな機能を統合している。 今回、 volume rendering 機能を用いた 3 次元透過 画像の有用性を実際の手術でもちいてその有用 性を検討したので報告する。

\section{2、方法}

MR 装置は 0.5T の縦型オープンタイプ MRI Signa SP/i (General Electric Medical Systems, Milwaukee, WI)を使用した。dual displayの PC 装置を準備し MR 装置に LAN で接続した。この独立した PC に MR-naviをインストールして使用した。 MR-naviにはMRコンソールを操作できる機能を 持たせた。Dual display の主画面は画像を表示し MR 磁石内のモニタに転送し術者に表示した。 Dual displayの副画面上でアプリケーションの設 定、MR画像の撮影条件の設定を行うようにした。 3、結果および考察

リアルタイム MR 画像と術直前の詳細な $3 \mathrm{D} の$ MR 画像を用いたリアルタイム撮影面での再構 
成画像の表示(inplane 0 , inplane90, perpendicular)に よる3D 画像ナビゲーションの実現した。またこ の MR-navi の MR コンソールコントロール機能 によって、温度画像カラー表示と温度画像ベース ラインの自動設定できるようにし、短時間で温度 画像に切り替えることができるようになった。腫 瘍領域および穿刺針進行予定ラインの $3 \mathrm{D}$ カラ 一表示および、3 次元透過画像によって、重要な 胆管や血管、胆囊などの他臓器を損傷することな く、より安全な治療ができるようになった。また 凝固治療範囲の記録と未治療領域の $3 \mathrm{D}$ 表示に より、正確な凝固療法が行えるようになった。 (Fig1) また今回 MR 装置コントロール機能をも たせスキャンの開始/停止、撮影パラメーターの 設定変更、手動、自動の撮影面切り替え、フット スイッチを使った術者による撮影面の切り替え、 穿刺針先端位置の手動微調整ができ手術時間の 短縮を可能とした。内視鏡画像の表示させ、胸腔 鏡や腹腔鏡の画面で確認しながら治療できるよ うにした。

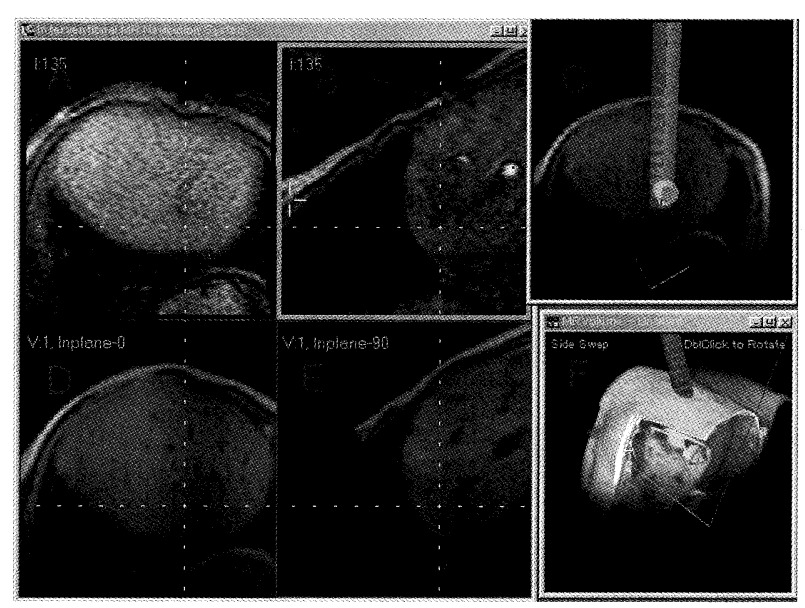

Fig.1

MR navi の実際。左上がリアルタイム MR 画像。 左下、中央上、中央下が術直前の MR 画像から再 構成画像。右上が 3 次元立体画像表示画面で治療 領域を記録することができる。右下が 3 次元透過 画像。黄色が腫瘍領域および緑色が穿刺針進行予 定ラインである。
結語

このソフトウエアは現在オープン MR 内でのイ ンターベンションに全症例使用され必須のもの となっている。

文献

1.Kurumi $\mathrm{Y}$, Tani $\mathrm{T}$, Naka $\mathrm{S}$, et al. Clinical Experiences with MR-Guided Microwave Ablation for Liver Tumors. ISMRM 9: 2204, 2001.

2.Morikawa S, Inubushi $\mathrm{T}$, Kurumi $\mathrm{Y}$, et al. MR-Guided Microwave Thermocoagulation Therapy of Liver Tumors: Initial Clinical Experiences Using a 0.5 T Open MR System. J Magn Reson Imaging 
04(XII)-99

ロボットのリンク構造を考慮した ZEUS 用術前プランニングシステム $\bigcirc$ 林部充宏 ${ }^{a}$, 鈴木直樹 ${ }^{a}$, 服部麻木 ${ }^{\mathrm{a}}$, 小西晃造 ${ }^{\mathrm{b}}$, 掛地吉弘 ${ }^{\mathrm{b}}$, 橋爪誠 ${ }^{\mathrm{b}}$

a 東京慈恵会医科大学高次元医用画像工学研究所, ${ }^{b}$ 九州大学病院先端医工学診療部

Preoperative planning system using kinematic computation of Zeus link structure Mitsuhiro Hayashibe ${ }^{\mathrm{a}}$, Naoki Suzuki ${ }^{\mathrm{a}}$, Asaki Hattori ${ }^{\mathrm{a}}$, Kozo Konishi ${ }^{\mathrm{b}}$, Yoshihiro Kakeji ${ }^{\mathrm{b}}$, Makoto Hashizume ${ }^{\mathrm{b}}$

${ }^{a}$ Inst. for High Dimensional Medical Imaging, Jikei Univ. School of Med., Tokyo, Japan

${ }^{\mathrm{b}}$ Center for Integration of Advanced Medicine and Innovative Technology,

Kyushu University Hospital, Fukuoka, Japan

\begin{abstract}
At present, there are representative robot operation systems such as da Vinci and ZEUS which realize minimally invasive surgery by use of dexterous manipulators. In the operating room, the medical staff have to prepare and set up the environment where the robot has optimal freedom of motion and the functions of robot can be fully demonstrated for every case. The range of motion in which the robot can reach and be maneuvered is restricted by the fixed point of trocar site. We have developed a preoperative planning system with the function of automatic positioning by applying an inverse-kinematics computation of ZEUS. The motion of surgical robot could be simulated in advance with the intuitive interface and kinematics computation program running in the background of this system. This kind of setup platform would be essential for the introduction of on-coming surgical robot.
\end{abstract}

Key words: Robot setup simulation, inverse-kinematics, preoperative trocar site planning

\section{1.はじめに}

1997 年に Cadiere らによって世界で初めてロボッ 卜を用いた胆囊摘出術が行われ, ロボット手術はそ の低侵襲性と正確な動作からあらゆる領域の手技 が試行され次世代手術として世界的に認められつ つある.代表的なものとして Intuitive Surgical 社の da Vinci や Computer Motion 社の ZEUS などが知 られる. 臨床の現場では第一に手術ロボットが最適 な運動を行い，その機能を充分に発揮できる環境 を症例ごとに整える作業が求められることから，これ を術前にシミュレーション可能としカンファレンス等で 術者・助手・看護師が事前にセットアップについて 検討を行えるda Vinci のプランニングシステム ${ }^{1)}$ を開 発し, 昨年度本学会にて報告した。本稿では Zeus システムに関しロボットの逆運動学計算によるリンク 構造を考慮した自動位置決め機能をもつ術前プラ ンニングシステムの開発を行った内容を報告する.

\section{ZEUS システム}

ZEUS はマスタースレーブ操作が可能な内視鏡 把持アームと 2 本の鉗子把持アームから構成されて いる. 3 本のアームは各々独立して手術台に取り付 けることが可能で設置自由度が高く, da Vinci に比 ベてコンパクトな設計となっている.しかしながら設 置自由度が高い分独立したアーム同士の干涉が起 きやすく,また共通の可動範囲を広くとるため現場
でのセットアップに費やされる時間が長い傾向があり, 術前プランニングシステムが必要であると考える.

Fig.1 に ZEUS システムのアームのリンク構造を示す. 3 つの能動関節, 1 つの固定関節, 2 つ受動関節 によって位置決めを行う構成が特徵的で, 腹部に 空けたトロカールの挿入点での拘束により 2 つの受 動関節のパラメータが決定される。

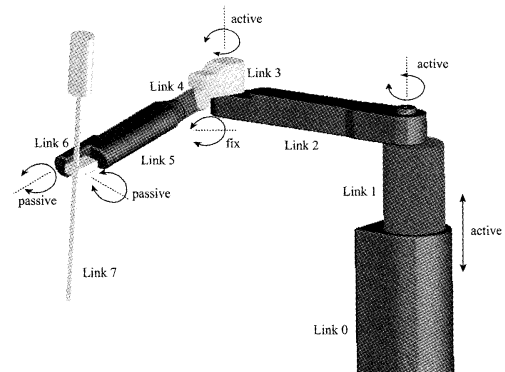

Fig. 1 Link structure of ZEUS manipulator

\section{3. システム構成}

ZEUS 本体の運動幾何モデルおよび3次元患者 モデルを用い, 手術ロボットのセットアップのシミュレ ーションを仮想空間上で行う. 仮想空閒上での 3 次 元位置入力装置としては PHANToM(SensAble Technologies Inc.)を用いた. Fig.2 に本システムの 処理手順を示す.体表に触れながら腹部形状を確 認しトロカールの位置を検討する際とロボットベース 位置を動かしながら決定する際には PHANToM に より対象との干渉の程度を力覚で表現することで直 
感的に操作可能とした。その他に補助的なガイドと して仮想的な内視鏡画像, アーム可動範囲の提示 とトロッカーサイト間の距離表示等がオペレータに表 示されるようにした。

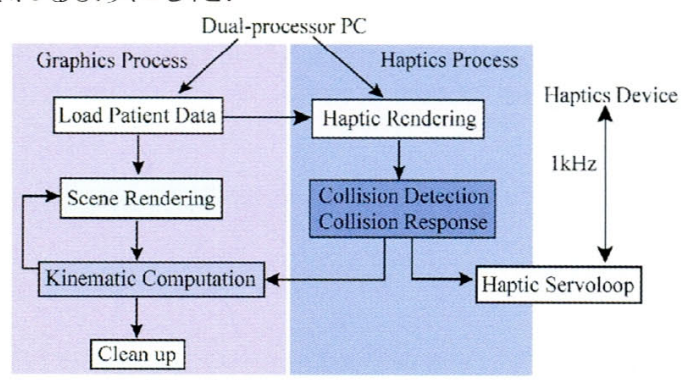

Fig. 2 Process overview

\section{4.リンク構造を考慮した自動位置決め機能}

トロカールの位置および対象患部の位置入力後 逆運動学計算によりロボットアームの各リンク位置が 自動的に位置決めされ即座に誘導される機能を持 たせた．毎フレーム逆運動学計算を行い, トロカー ル㧙入点決定後はその拘束条件を反映した位置 決めが行われる。例えげトロカール位置決定後，ロ ボットベース位置をスライドさせても鉗子は必ず挿入 点を通るよう仮想空間上のロボットの動作が生成さ れる.ZEUS システムでは 2 つの受動関節があるた めヤコビアンを求める際には, 拘束条件に基づき受 動関節のパラメータを 3 つの能動関節のパラメータ を用いた線形和として算出するようにした。

また対象患部の位置入力を行うと鉗子先端部が その点に収束するように誘導される. Fig.3 にその際 のマニピュレータの軌跡の例を示す。目標位置が運 動学上の特異点など到達不可能なア一ム姿勢に陥 る場合には再入力するものとした. Fig.4 に胆囊位 置を入力した後 3 本のアームが自動的に誘導され ていく様子走示す、内視鏡が対象を中央に映しそ の両側に鉗子が到達するようにセットアップされる様 子学見ることができる。

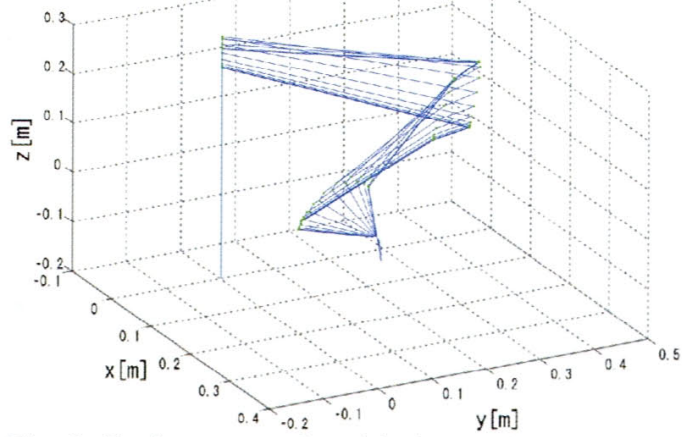

Fig.3 Trajectory of guided manipulator to target position by inverse-kinematics computation.

\section{4.おわりに}

手術ロボットの逆運動学を考慮した自動位置決 め機能をもつ ZEUS 用術前プランニングシステムの 開発を行った。手術台に固定する 3 台のロボットの 位置関係・卜ロカール位置・対象部位から一意に決 定されるインターフェースにより直感的に短時間で セットアップのシミュレーションを行うことができた。今 後具体的な臨床例において本システムによるセット アップ時間の短縮効果などを評価する予定である.

\section{文献}

1) 林部充宏,鈴木直樹,服部麻木, 鈴木薰之, 小西晃造, 掛 地吉弘, 橋爪誠。手術ロボットの最適な運動・機器配㯰の ための術前プランニングシステムの開発。電子情報通信 学会誌,Vol.J87-D-II,No.12, 2004.(in print)

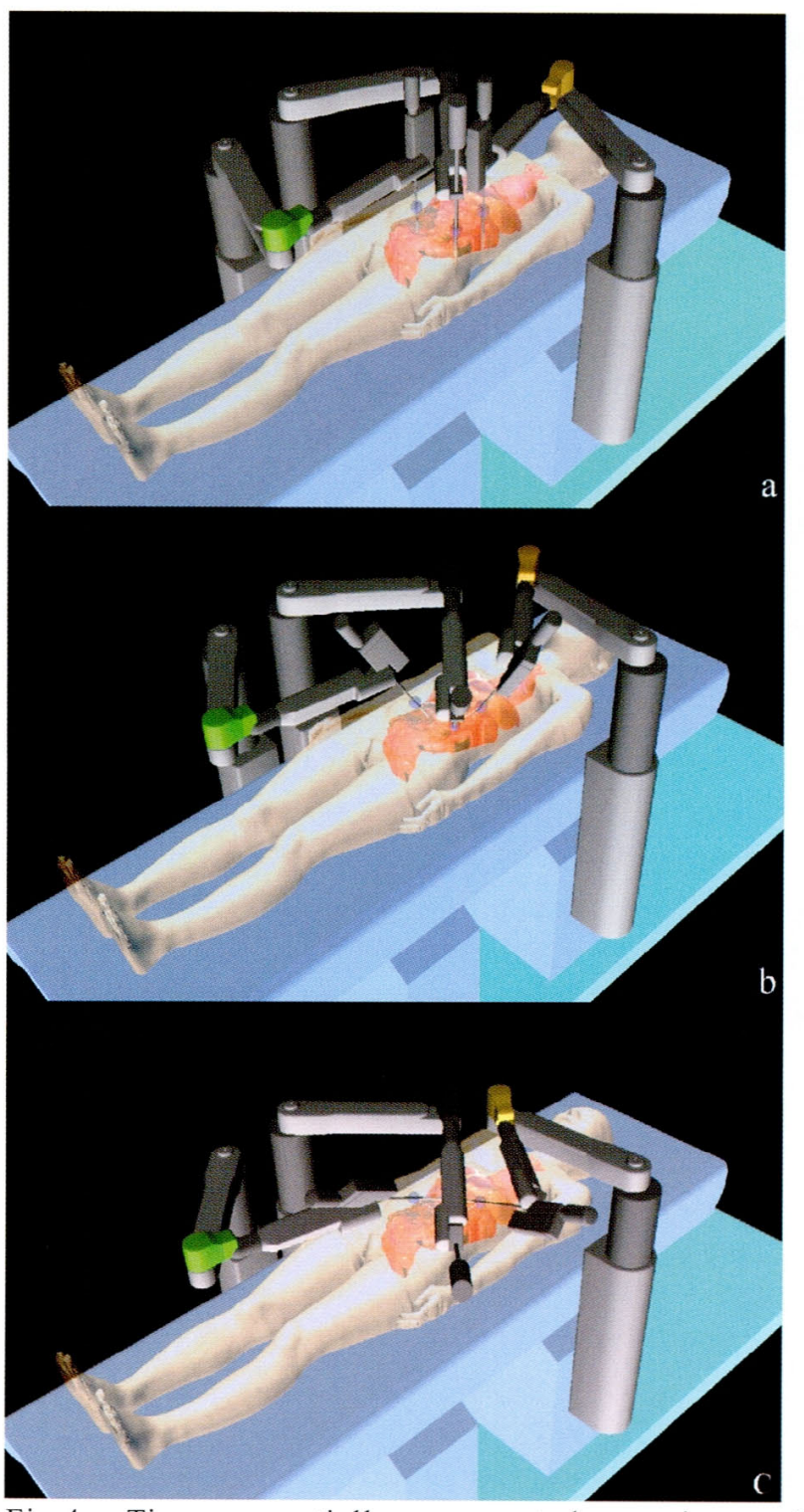

Fig.4 Time-sequentially generated motion of automatically guided ZEUS robot to a gallbladder. 